\title{
Characterization of gas-phase organics using proton transfer reaction time-of-flight mass spectrometry: fresh and aged residential wood combustion emissions
}

\author{
Emily A. Bruns ${ }^{1}$, Jay G. Slowik ${ }^{1}$, Imad El Haddad ${ }^{1}$, Dogushan Kilic ${ }^{1}$, Felix Klein ${ }^{1}$, Josef Dommen ${ }^{1}$, \\ Brice Temime-Roussel $^{2}$, Nicolas Marchand ${ }^{2}$, Urs Baltensperger ${ }^{1}$, and André S. H. Prévôt ${ }^{1}$ \\ ${ }^{1}$ Laboratory of Atmospheric Chemistry, Paul Scherrer Institute, 5232 Villigen, Switzerland \\ ${ }^{2}$ Aix Marseille Univ, CNRS, LCE, Laboratoire de Chimie de l'Environnement, UMR7376, 13331, Marseille, France
}

Correspondence to: Emily A. Bruns (emilybruns@gmail.com) and André S. H. Prévôt (andre.prevot@psi.ch)

Received: 21 August 2016 - Published in Atmos. Chem. Phys. Discuss.: 30 August 2016

Revised: 1 December 2016 - Accepted: 11 December 2016 - Published: 16 January 2017

\begin{abstract}
Organic gases emitted during the flaming phase of residential wood combustion are characterized individually and by functionality using proton transfer reaction time-offlight mass spectrometry. The evolution of the organic gases is monitored during photochemical aging. Primary gaseous emissions are dominated by oxygenated species (e.g., acetic acid, acetaldehyde, phenol and methanol), many of which have deleterious health effects and play an important role in atmospheric processes such as secondary organic aerosol formation and ozone production. Residential wood combustion emissions differ considerably from open biomass burning in both absolute magnitude and relative composition. Ratios of acetonitrile, a potential biomass burning marker, to $\mathrm{CO}$ are considerably lower $\left(\sim 0.09 \mathrm{pptv}_{\mathrm{ppbv}}{ }^{-1}\right)$ than those observed in air masses influenced by open burning $(\sim 1-$ 2 pptv ppbv ${ }^{-1}$ ), which may make differentiation from background levels difficult, even in regions heavily impacted by residential wood burning. A considerable amount of formic acid forms during aging $\left(\sim 200-600 \mathrm{mg} \mathrm{kg}^{-1}\right.$ at an $\mathrm{OH}$ exposure of $(4.5-5.5) \times 10^{7}$ molec $\mathrm{cm}^{-3} \mathrm{~h}$ ), indicating residential wood combustion can be an important local source for this acid, the quantities of which are currently underestimated in models. Phthalic anhydride, a naphthalene oxidation product, is also formed in considerable quantities with aging $\left(\sim 55-75 \mathrm{mg} \mathrm{kg}^{-1}\right.$ at an $\mathrm{OH}$ exposure of (4.5$5.5) \times 10^{7}$ molec $\mathrm{cm}^{-3} \mathrm{~h}$ ). Although total NMOG emissions vary by up to a factor of $\sim 9$ between burns, SOA formation potential does not scale with total NMOG emissions and is similar in all experiments. This study is the first thorough characterization of both primary and aged organic gases from
\end{abstract}

residential wood combustion and provides a benchmark for comparison of emissions generated under different burn parameters.

\section{Introduction}

Residential wood combustion is a source of gaseous and particulate emissions in the atmosphere, including a complex mixture of non-methane organic gases (NMOGs; McDonald et al., 2000; Schauer et al., 2001; Hedberg et al., 2002; Jordan and Seen, 2005; Pettersson et al., 2011; Evtyugina et al., 2014; Reda et al., 2015). NMOGs impact climate (IPCC, 2013) and health (Pouli et al., 2003; Bølling et al., 2009) both directly and through the formation of products during atmospheric processing (Mason et al., 2001; Kroll and Seinfeld, 2008; Shao et al., 2009), which makes NMOG characterization critical. Although two studies have speciated a large fraction of the NMOG mass emitted during residential wood combustion in commercial burners (McDonald et al., 2000; Schauer et al., 2001), these studies relied on offline chromatographic approaches, which are time consuming in terms of sample preparation and analysis and can introduce both positive and negative artifacts (Nozière et al., 2015). Relatively recently, the proton transfer reaction mass spectrometer (PTR-MS) has emerged as a powerful tool for online quantification of atmospherically relevant NMOGs (Lindinger et al., 1998; Jordan et al., 2009), eliminating many of the artifacts associated with offline approaches. NMOGs emitted during open burning of a variety of biomass fu- 
els in the laboratory have been recently quantified using a high-resolution proton transfer reaction time-of-flight mass spectrometer (PTR-ToF-MS; Stockwell et al., 2015), and select nominal masses were followed during aging of residential wood combustion emissions using a quadrupole PTRMS (Grieshop et al., 2009a). However, a complete highresolution characterization of residential wood combustion emissions has yet to be performed.

The quantities and composition of NMOGs emitted during residential wood combustion are highly dependent on a number of parameters including wood type, appliance type and burn conditions, and as few studies have characterized these NMOGs (McDonald et al., 2000; Schauer et al., 2001; Hedberg et al., 2002; Jordan and Seen, 2005; Pettersson et al., 2011; Evtyugina et al., 2014; Reda et al., 2015), further work is needed to constrain emission factors, as highlighted in the recent review article by Nozière et al. (2015). Also, little is known about the evolution of NMOGs from residential wood combustion with aging.

In this study, we present results from the first use of a smog chamber and a PTR-ToF-MS to characterize primary and aged gaseous emissions from residential wood combustion in real time. This novel approach allows for an improved characterization of NMOG emissions, particularly oxygenated NMOGs, which are a considerable fraction of the total NMOG mass emitted during residential wood combustion (McDonald et al., 2000; Schauer et al., 2001). This study focuses on a narrow set of burn conditions, namely the flaming phase of beech wood combustion, in order to generate emissions that are as reproducible as possible for a complementary investigation of the effects of parameters such as temperature on the emissions. While these experiments are a narrow representation of real-world conditions, this novel work provides a benchmark and direction for future wood combustion studies.

\section{Methods}

\subsection{Emission generation and smog chamber operation}

Beech (Fagus sylvatica) logs are combusted in a residential wood burner (Fig. S1 in the Supplement; single combustion chamber, operated in single batch mode; Avant, 2009, Attika) and emissions are sampled from the chimney through a heated line $(473 \mathrm{~K})$, diluted by a factor of $\sim 8-10$ using an ejector diluter (473 K, DI-1000, Dekati Ltd.) and injected into the smog chamber $\left(\sim 7 \mathrm{~m}^{3}\right)$ through a heated line $(423 \mathrm{~K})$. Emissions are sampled during the stable flaming phase of the burn and modified combustion efficiencies (MCEs), defined as the ratio between $\mathrm{CO}_{2}$ and the sum of $\mathrm{CO}$ and $\mathrm{CO}_{2}$ range from 0.974 to 0.978 (Table 1).

Emissions are injected for 11-21 min and total dilution factors range from $\sim 100-200$. All experiments are conducted under similar conditions with starting wood masses in the burner of $2.9 \pm 0.3 \mathrm{~kg}$ and a wood moisture content of $19 \pm 2 \%$. The smog chamber has an average temperature of $287.0 \pm 0.1 \mathrm{~K}$ and a relative humidity of $55 \pm 3 \%$ over all five experiments. Experimental parameters and primary emission values are summarized in Table S1 in the Supplement. After characterization of the primary emissions, as described below, a single dose of d9-butanol ( $2 \mu \mathrm{L}$, butanolD9, $98 \%$, Cambridge Isotope Laboratories) is injected into the chamber and a continuous injection of nitrous acid in air (2.3-2.6 $\mathrm{L} \mathrm{min}^{-1}, \geq 99.999 \%$, Air Liquide) into the chamber begins. The decay of d9-butanol measured throughout aging is used to estimate hydroxyl radical $(\mathrm{OH})$ exposures (Barmet et al., 2012). Nitrous acid produces OH upon irradiation in the chamber and is used to increase the degree of aging. Levels of $\mathrm{NO}_{x}$ in the chamber prior to aging are in the range of $\sim 160-350$ and increase to $\sim 250-380 \mathrm{ppbv}$ after reaching $\mathrm{OH}$ exposures of $\sim(4.5-5.5) \times 10^{7} \mathrm{molec} \mathrm{cm}^{-3} \mathrm{~h}$ $\left(\mathrm{NO}_{x}\right.$ data unavailable for experiment 1). The small continuous dilution in the chamber during aging, due to the constant nitrous acid injection, is accounted for using $\mathrm{CO}$ as an inert tracer. The chamber contents are irradiated with UV light (40 lights, 90-100 W, Cleo Performance, Philips; Platt et al., 2013) for 4.5-6h (maximum $\mathrm{OH}$ exposures of (4.7-6.8) $\times 10^{7} \mathrm{molec}^{-3} \mathrm{~h}$ which corresponds to $\sim 2-3$ days of aging in the atmosphere at an $\mathrm{OH}$ concentration of $1 \times 10^{6}$ molec $\left.\mathrm{cm}^{-3}\right)$. Reported quantities of aged species are taken at $\mathrm{OH}$ exposures of $(4.5-5.5) \times 10^{7} \mathrm{molec} \mathrm{cm}^{-3} \mathrm{~h}$ (Table 1; 1.9-2.3 days of aging in the atmosphere at an $\mathrm{OH}$ concentration of $1 \times 10^{6} \mathrm{molec} \mathrm{cm}^{-3}$; Barmet et al., 2012).

\subsection{Gas-phase analysis}

NMOGs with a proton affinity greater than that of water are measured using a PTR-ToF-MS (PTR-ToF-MS 8000, Ionicon Analytik $\mathrm{GmbH}$ ) and $\mathrm{CO}_{2}, \mathrm{CO}$ and $\mathrm{CH}_{4}$ are measured using cavity ring-down spectroscopy (G2401, Picarro, Inc.). The PTR-ToF-MS operates with hydronium ion $\left(\left[\mathrm{H}_{2} \mathrm{O}+\mathrm{H}\right]^{+}\right)$as the reagent, a drift tube pressure of $2.2 \mathrm{mbar}$, a drift tube voltage of $543 \mathrm{~V}$ and a drift tube temperature of $90^{\circ} \mathrm{C}$ leading to a ratio of the electric field $(E)$ and the density of the buffer gas $(N)$ in the drift tube (reduced electric field, $E / N$ ) of 137 Townsend (Td). The transmission function is determined using a gas standard of six NMOGs of known concentration (methanol, acetaldehyde, propan-2one, toluene, $p$-xylene, 1,3,5-trimethylbenzene; Carbagas). As the RH and temperature of the sampled air is similar in all experiments, changes in the detection efficiency of individual species are not expected.

PTR-ToF-MS data are analyzed using the Tofware postprocessing software (version 2.4.5, TOFWERK AG, Thun, Switzerland; PTR module as distributed by Ionicon Analytik $\mathrm{GmbH}$ ), running in the Igor Pro 6.3 environment (version 6.3, Wavemetrics Inc.). The minimum detection limit is taken as 3 standard deviations above the background, where the standard deviation is determined from the measurements 
Table 1. Modified combustion efficiencies, $\mathrm{OH}$ exposures of reported aged values $\left(\operatorname{molec~} \mathrm{cm}^{-3} \mathrm{~h}\right)$ and enhancement of select species relative to $\mathrm{CO}$ enhancement above background levels ( $\operatorname{pptv}_{\mathrm{ppbv}}{ }^{-1}$ ).

\begin{tabular}{lrrrrrr}
\hline & \multicolumn{7}{c}{ Experiment } & \\
\cline { 2 - 5 } Parameter & 1 & 2 & 3 & 4 & 5 & Average* $^{*}$ \\
\hline MCE & 0.975 & 0.978 & 0.977 & 0.974 & 0.978 & $0.976 \pm 0.002$ \\
OH exposure & $4.5 \times 10^{7}$ & $5.5 \times 10^{7}$ & $5.3 \times 10^{7}$ & $5.2 \times 10^{7}$ & $4.7 \times 10^{7}$ & - \\
$\Delta \mathrm{CH}_{3} \mathrm{CN}_{\text {primary }} / \Delta \mathrm{CO}$ & 0.079 & 0.11 & 0.099 & 0.077 & 0.082 & $0.09 \pm 0.01$ \\
$\Delta \mathrm{CH}_{3} \mathrm{CN}_{\text {aged }} / \Delta \mathrm{CO}$ & 0.084 & 0.11 & 0.11 & 0.072 & 0.069 & $0.09 \pm 0.02$ \\
$\Delta \mathrm{CH}_{3} \mathrm{OH}_{\text {primary }} / \Delta \mathrm{CO}$ & 3.4 & 21 & 11 & 2.4 & 1.5 & $8 \pm 8$ \\
$\Delta \mathrm{CH}_{3} \mathrm{OH}_{\text {aged }} / \Delta \mathrm{CO}$ & 3.4 & 19 & 11 & 2.5 & 1.8 & $7 \pm 7$ \\
$\Delta \mathrm{C}_{2} \mathrm{H}_{4} \mathrm{O}_{2 \text { primary }} / \Delta \mathrm{CO}$ & 12 & 84 & 57 & 9.8 & 5.9 & $30 \pm 30$ \\
$\Delta \mathrm{C}_{2} \mathrm{H}_{4} \mathrm{O}_{\text {2aged }} / \Delta \mathrm{CO}$ & 12 & 68 & 48 & 9.4 & 6.5 & $30 \pm 30$ \\
\hline
\end{tabular}

* Uncertainties correspond to one sample standard deviation of the replicates.

of each ion in the chamber prior to emission injection. Isotopic contributions are constrained during peak fitting and are accounted for in reported concentrations. Possible molecular formulas increase with increasing $m / z$, making accurate peak assignments difficult in the higher $m / z$ range. Mass spectral data from $m / z 33$ to $m / z, 130$ are assigned molecular formulas, as well as the ${ }^{18} \mathrm{O}$ isotope of the reagent ion and signal above $m / z 130$ corresponding to compounds previously identified during residential wood combustion (McDonald et al., 2000; Schauer et al., 2001; Hedberg et al., 2002; Jordan and Seen, 2005; Pettersson et al., 2011; Evtyugina et al., 2014; Reda et al., 2015). All signal above $m / z 130$ is included in total NMOG mass quantification. Using this approach, 94-97\% of the total NMOG mass measured using the PTR-ToF-MS has an ion assignment.

The reaction rate constant of each species with the reagent ion in the drift tube is needed to convert raw signal to concentration. When available, individual reaction rate constants are applied to ions assigned a structure (Cappellin et al., 2012; Table S2), otherwise a default reaction rate constant of $2 \times 10^{-9} \mathrm{~cm}^{3} \mathrm{~s}^{-1}$ is applied. For possible isomers, the reaction rate constant is taken as the average of available values. Approximately $60-70 \%$ of the total NMOG mass is comprised of compounds with known rate constants. NMOG signal is normalized to $\left[\mathrm{H}_{2}^{18} \mathrm{O}+\mathrm{H}\right]^{+}$to convert to concentration. Emission factors (EFs) normalize concentrations to the total wood mass burned (e.g., $\mathrm{mg} \mathrm{kg}^{-1}$ reads as milligrams of species emitted per kilogram of wood burned) to facilitate comparison between experiments and are calculated as described previously (Andreae and Merlet, 2001; Bruns et al., 2015a).

PTR-ToF mass spectrometry is a relatively soft ionization technique generally resulting in protonation of the parent NMOG $\left([\mathrm{M}+\mathrm{H}]^{+}\right)$, although some compounds are known to produce other ions, for example through fragmentation or rearrangement (e.g., Baasandorj et al., 2015). Reactions potentially leading to considerable formation of species besides $[\mathrm{M}+\mathrm{H}]^{+}$are discussed in the Supplement. The extent to which reactions leading to ions other than $[\mathrm{M}+\mathrm{H}]^{+}$occurs is dependent on instrument parameters such as $E / N$. The unknown relative contributions of various isomers makes it difficult to account for reactions generating ions besides $[\mathrm{M}+\mathrm{H}]^{+}$and thus, no fragmentation corrections are applied. Emission factors of compounds likely to undergo extensive reactions to form products besides $[\mathrm{M}+\mathrm{H}]^{+}$(i.e., methylcyclohexane (Midey et al., 2003), ethyl acetate (Baasandorj et al., 2015) and saturated aliphatic aldehydes (Buhr et al., 2002), with the exception of acetaldehyde) are not reported. Due to interferences, butenes $\left(\left[\mathrm{C}_{4} \mathrm{H}_{8}+\mathrm{H}\right]^{+}\right)$are not quantified.

\section{Results and discussion}

\subsection{NMOG emissions}

In all experiments, the largest $\mathrm{EFs}$ for a single gas-phase species correspond to $\mathrm{CO}_{2}\left(1770-1790 \mathrm{~g} \mathrm{~kg}^{-1}\right)$ and $\mathrm{CO}(27-$ $30 \mathrm{~g} \mathrm{~kg}^{-1}$; Table 2), which are in good agreement with previous measurements from residential beech logwood combustion where $\mathrm{CO}_{2}$ EFs of $\sim 1800$ and CO EFs of $\sim 20$ $70 \mathrm{~g} \mathrm{~kg}^{-1}$ were measured (Ozil et al., 2009; Schmidl et al., 2011; Kistler et al., 2012; Evtyugina et al., 2014; Reda et al., 2015). Methane is also emitted in considerable quantities $\left(1.5-2.8 \mathrm{~g} \mathrm{~kg}^{-1}\right)$, similar to previously observed values for beech wood burning in fireplaces $\left(0.5-1 \mathrm{~g} \mathrm{~kg}^{-1}\right.$; Ozil et al., 2009), although at generally lower levels than total NMOGs $\left(1.5-13 \mathrm{~g} \mathrm{~kg}^{-1}\right)$. Total NMOG EFs from beech wood combustion have not been previously reported, but values are similar to studies of residential wood stove burning of different hardwoods which have attempted a detailed quantification of total NMOGs, such as McDonald et al. (2000; $6.2-55.3 \mathrm{~g} \mathrm{~kg}^{-1}$ for a hardwood mixture) and Schauer et al. (2001; $6.7 \mathrm{~g} \mathrm{~kg}^{-1}$ for oak). Total NMOG quantities reported in this study refer to species quantified using the PTRToF-MS. 
Table 2. Primary emission factors of gas-phase species $\left(\mathrm{mg} \mathrm{kg}^{-1}\right)^{\mathrm{a}, \mathrm{b}}$.

\begin{tabular}{|c|c|c|c|c|c|c|c|c|c|}
\hline \multirow[t]{2}{*}{ Species } & \multirow{2}{*}{$\begin{array}{r}\text { Monoisotopic } \\
\mathrm{m} / \mathrm{z}\end{array}$} & \multirow[t]{2}{*}{ Structural assignment $^{\mathrm{c}}$} & \multirow[t]{2}{*}{ Functional group } & \multicolumn{5}{|c|}{ Experiment } & \multirow[t]{2}{*}{ Average $^{\mathrm{d}}$} \\
\hline & & & & 1 & 2 & 3 & 4 & 5 & \\
\hline $\mathrm{CO}_{2}$ & & & & 1780000 & 1781000 & 1777000 & 1772000 & 1784000 & $1779000 \pm 4000$ \\
\hline $\mathrm{CO}$ & & & & 27000 & 26000 & 27000 & 30000 & 27000 & $28000 \pm 2000$ \\
\hline $\mathrm{CH}_{4}$ & & & & 1800 & 1600 & 2000 & 2800 & 1500 & $1900 \pm 500$ \\
\hline NMOG & & & & 2800 & 13000 & 9200 & 3200 & 1500 & $6000 \pm 5000$ \\
\hline acid & & & & 750 & 5000 & 3500 & 700 & 340 & $2000 \pm 2000$ \\
\hline O-containing & & & & 560 & 3400 & 2200 & 590 & 290 & $1000 \pm 1000$ \\
\hline carbonyl & & & & 310 & 1500 & 960 & 270 & 170 & $600 \pm 600$ \\
\hline oxygenated aromatic & & & & 230 & 780 & 520 & 270 & 140 & $400 \pm 300$ \\
\hline alcohol & & & & 130 & 660 & 360 & 90 & 48 & $300 \pm 300$ \\
\hline furan & & & & 93 & 680 & 410 & 95 & 51 & $300 \pm 300$ \\
\hline $\mathrm{O}$ - and $\mathrm{N}$-containing & & & & 120 & 81 & 77 & 120 & 91 & $100 \pm 20$ \\
\hline $\mathrm{C}_{x} \mathrm{H}_{y}$ & & & & 120 & 210 & 210 & 160 & 64 & $150 \pm 60$ \\
\hline aromatic hydrocarbon & & & & 320 & 170 & 490 & 680 & 250 & $400 \pm 200$ \\
\hline $\mathrm{N}$-containing & & & & 20 & 39 & 36 & 23 & 16 & $30 \pm 10$ \\
\hline other & & & & 140 & 390 & 310 & 160 & 94 & $200 \pm 100$ \\
\hline$\left[\mathrm{CH}_{3} \mathrm{OH}+\mathrm{H}\right]^{+}$ & 33.034 & methanol & alcohol & 110 & 660 & 360 & 87 & 47 & $300 \pm 300$ \\
\hline$\left[\mathrm{C}_{2} \mathrm{H}_{3} \mathrm{~N}+\mathrm{H}\right]^{+}$ & 42.034 & acetonitrile & $\mathrm{N}$-containing & 3.4 & 3.4 & 4.1 & 3.6 & 3.2 & $3.5 \pm 0.3$ \\
\hline$\left[\mathrm{C}_{3} \mathrm{H}_{6}+\mathrm{H}\right]^{+}$ & 43.055 & propene & $\mathrm{C}_{x} \mathrm{H}_{y}$ & 38 & 61 & 40 & 28 & 15 & $40 \pm 20$ \\
\hline$\left[\mathrm{C}_{2} \mathrm{H}_{4} \mathrm{O}+\mathrm{H}\right]^{+}$ & 45.034 & acetaldehyde & carbonyl & 94 & 330 & 230 & 79 & 48 & $200 \pm 100$ \\
\hline$\left[\mathrm{CH}_{2} \mathrm{O}_{2}+\mathrm{H}\right]+$ & 47.013 & formic acid & acid & 9.9 & 96 & 100 & 31 & 4.2 & $50 \pm 50$ \\
\hline$\left[\mathrm{C}_{2} \mathrm{H}_{6} \mathrm{O}+\mathrm{H}\right]^{+}$ & 47.050 & ethanol & alcohol & 16 & BDL & 3.3 & 2.5 & BDL & $4 \pm 7$ \\
\hline$\left[\mathrm{C}_{4} \mathrm{H}_{6}+\mathrm{H}\right]^{+}$ & 55.055 & buta-1,3-diene & $\mathrm{C}_{x} \mathrm{H}_{y}$ & 14 & 38 & 33 & 14 & 5.7 & $20 \pm 10$ \\
\hline$\left[\mathrm{C}_{3} \mathrm{H}_{4} \mathrm{O}+\mathrm{H}\right]^{+}$ & 57.034 & prop-2-enal & carbonyl & 45 & 160 & 120 & 45 & 25 & $80 \pm 60$ \\
\hline$\left[\mathrm{C}_{2} \mathrm{H}_{2} \mathrm{O}_{2}+\mathrm{H}\right]^{+}$ & 59.013 & glyoxal & carbonyl & BDL & BDL & BDL & 1.3 & BDL & $0.3 \pm 0.6$ \\
\hline$\left[\mathrm{C}_{3} \mathrm{H}_{6} \mathrm{O}+\mathrm{H}\right]^{+}$ & 59.050 & $\begin{array}{l}\text { propan-2-one } \\
\text { propanal }\end{array}$ & carbonyl & 54 & 190 & 120 & 30 & 30 & $80 \pm 70$ \\
\hline$\left[\mathrm{C}_{2} \mathrm{H}_{4} \mathrm{O}_{2}+\mathrm{H}\right]^{+}$ & 61.029 & $\begin{array}{l}\text { acetic acid } \\
\text { glycolaldehyde }\end{array}$ & acid & 740 & 4900 & 3400 & 670 & 340 & $2000 \pm 2000$ \\
\hline$\left[\mathrm{C}_{4} \mathrm{H}_{4} \mathrm{O}+\mathrm{H}\right]^{+}$ & 69.034 & furan & furan & 17 & 140 & 82 & 19 & 9.7 & $50 \pm 60$ \\
\hline$\left[\mathrm{C}_{5} \mathrm{H}_{8}+\mathrm{H}\right]^{+}$ & 69.070 & $\begin{array}{l}\text { isoprene } \\
\text { cyclopentene }\end{array}$ & $\mathrm{C}_{x} \mathrm{H}_{y}$ & 3.4 & 12 & 9.4 & 2.8 & 1.1 & $3 \pm 2$ \\
\hline$\left[\mathrm{C}_{4} \mathrm{H}_{6} \mathrm{O}+\mathrm{H}\right]^{+}$ & 71.050 & $\begin{array}{l}(E) \text {-but-2-enal } \\
\text { 3-buten-2-one }\end{array}$ & $\begin{array}{l}\text { carbonyl } \\
\text { 2-methylprop-2-enal }\end{array}$ & 25 & 120 & 72 & 19 & 14 & $50 \pm 40$ \\
\hline$\left[\mathrm{C}_{5} \mathrm{H}_{10}+\mathrm{H}\right]^{+}$ & 71.086 & $\begin{array}{l}(E) \text {-/( } Z) \text {-pent-2-ene } \\
\text { 2-methylbut-1-ene } \\
\text { 2-methylbut-2-ene } \\
\text { pent-1-ene } \\
\text { 3-methylbut-1-ene }\end{array}$ & $\mathrm{C}_{x} \mathrm{H}_{y}$ & 2.7 & 5.3 & 4.0 & 2.0 & 0.86 & $3 \pm 2$ \\
\hline$\left[\mathrm{C}_{3} \mathrm{H}_{4} \mathrm{O}_{2}+\mathrm{H}\right]^{+}$ & 73.029 & 2-oxopropanal & carbonyl & 26 & 140 & 96 & 26 & 15 & $60 \pm 50$ \\
\hline$\left[\mathrm{C}_{4} \mathrm{H}_{8} \mathrm{O}+\mathrm{H}\right]^{+}$ & 73.065 & $\begin{array}{l}\text { butan-2-one } \\
\text { butanal }\end{array}$ & carbonyl & 7.2 & 44 & 24 & 5.2 & 4.2 & $20 \pm 20$ \\
\hline$\left[\mathrm{C}_{3} \mathrm{H}_{6} \mathrm{O}_{2}+\mathrm{H}\right]^{+}$ & 75.045 & $\begin{array}{l}\text { 2-methylpropanal } \\
\text { methyl acetate }\end{array}$ & O-containing & 62 & 490 & 300 & 56 & 28 & $200 \pm 200$ \\
\hline$\left[\mathrm{C}_{6} \mathrm{H}_{6}+\mathrm{H}\right]^{+}$ & 79.055 & benzene & aromatic hydrocarbon & 210 & 90 & 300 & 450 & 150 & $200 \pm 100$ \\
\hline$\left[\mathrm{C}_{5} \mathrm{H}_{6} \mathrm{O}+\mathrm{H}\right]^{+}$ & 83.050 & 2-methylfuran & furan & 21 & 160 & 88 & 21 & 12 & $60 \pm 60$ \\
\hline$\left[\mathrm{C}_{5} \mathrm{H}_{8} \mathrm{O}+\mathrm{H}\right]^{+}$ & 85.065 & 3-methyl-3-buten-2-one & carbonyl & 10 & 69 & 39 & 8.7 & 5.4 & $30 \pm 30$ \\
\hline$\left[\mathrm{C}_{6} \mathrm{H}_{12}+\mathrm{H}\right]^{+}$ & 85.102 & $\begin{array}{l}(E) \text {-hex-2-ene } \\
\text { 2-methyl-pent-2-ene }\end{array}$ & $\mathrm{C}_{x} \mathrm{H}_{y}$ & BDL & 2.2 & 1.6 & 0.60 & BDL & $1 \pm 1$ \\
\hline$\left[\mathrm{C}_{4} \mathrm{H}_{6} \mathrm{O}_{2}+\mathrm{H}\right]^{+}$ & 87.045 & butane-2,3-dione & carbonyl & 51 & 450 & 250 & 52 & 26 & $200 \pm 200$ \\
\hline$\left[\mathrm{C}_{7} \mathrm{H}_{8}+\mathrm{H}\right]^{+}$ & 93.070 & toluene & aromatic hydrocarbon & 23 & 22 & 34 & 39 & 16 & $27 \pm 9$ \\
\hline$\left[\mathrm{C}_{6} \mathrm{H}_{6} \mathrm{O}+\mathrm{H}\right]^{+}$ & 95.050 & phenol & oxygenated aromatic & 110 & 110 & 130 & 130 & 68 & $110 \pm 20$ \\
\hline$\left[\mathrm{C}_{5} \mathrm{H}_{4} \mathrm{O}_{2}+\mathrm{H}\right]^{+}$ & 97.029 & furan-2-carbaldehyde & furan & 40 & 270 & 180 & 40 & 21 & $100 \pm 100$ \\
\hline$\left[\mathrm{C}_{6} \mathrm{H}_{8} \mathrm{O}+\mathrm{H}\right]^{+}$ & 97.065 & 2,4-/2,5-dimethylfuran & furan & 11 & 86 & 48 & 11 & 5.5 & $30 \pm 30$ \\
\hline$\left[\mathrm{C}_{4} \mathrm{H}_{2} \mathrm{O}_{3}+\mathrm{H}\right]^{+}$ & 99.008 & maleic anhydride $\mathrm{e}^{\mathrm{e}}$ & O-containing & 40 & 91 & 66 & 40 & 26 & $50 \pm 30$ \\
\hline$\left[\mathrm{C}_{8} \mathrm{H}_{8}+\mathrm{H}\right]^{+}$ & 105.070 & styrene & aromatic hydrocarbon & 12 & 8.0 & 20 & 24 & 9.6 & $15 \pm 7$ \\
\hline$\left[\mathrm{C}_{7} \mathrm{H}_{6} \mathrm{O}+\mathrm{H}\right]^{+}$ & 107.050 & benzaldehyde & oxygenated aromatic & 18 & 14 & 23 & 27 & 11 & $18 \pm 7$ \\
\hline$\left[\mathrm{C}_{8} \mathrm{H}_{10}+\mathrm{H}\right]^{+}$ & 107.086 & $\begin{array}{l}m \text {-/o-/p-xylene } \\
\text { ethylbenzene }\end{array}$ & aromatic hydrocarbon & 4.2 & 6.9 & 7.5 & 6.3 & 2.9 & $6 \pm 2$ \\
\hline$\left[\mathrm{C}_{7} \mathrm{H}_{8} \mathrm{O}+\mathrm{H}\right]^{+}$ & 109.065 & $m-/ o-/ p$-cresol & oxygenated aromatic & 24 & 71 & 48 & 25 & 14 & $40 \pm 20$ \\
\hline$\left[\mathrm{C}_{6} \mathrm{H}_{6} \mathrm{O}_{2}+\mathrm{H}\right]^{+}$ & 111.045 & $\begin{array}{l}m \text {-/o-/p-benzenediol } \\
\text { 2-methylfuraldehyde }\end{array}$ & oxygenated aromatic & 26 & 150 & 86 & 22 & 14 & $60 \pm 50$ \\
\hline$\left[\mathrm{C}_{9} \mathrm{H}_{8}+\mathrm{H}\right]^{+}$ & 117.070 & $1 H$-indene & aromatic hydrocarbon & 5.0 & BDL & 9.5 & 15 & 2.9 & $6 \pm 6$ \\
\hline$\left[\mathrm{C}_{9} \mathrm{H}_{10}+\mathrm{H}\right]^{+}$ & 119.086 & 2,3-dihydro- $1 H$-indene & aromatic hydrocarbon & 2.3 & 2.8 & 3.9 & 3.3 & 1.3 & $3 \pm 1$ \\
\hline$\left[\mathrm{C}_{8} \mathrm{H}_{8} \mathrm{O}+\mathrm{H}\right]^{+}$ & 121.065 & 1-phenylethanone 3-/4-methylbenzaldehyde & oxygenated aromatic & 8.3 & 14 & 13 & 8.8 & 4.6 & $10 \pm 4$ \\
\hline$\left[\mathrm{C}_{9} \mathrm{H}_{12}+\mathrm{H}\right]^{+}$ & 121.102 & $\begin{array}{l}i \text {-propylbenzene } \\
n \text {-propylbenzene } \\
1,3,5 \text {-trimethylbenzene }\end{array}$ & aromatic hydrocarbon & 1.0 & 2.4 & 2.3 & 1.2 & 0.68 & $1.5 \pm 0.8$ \\
\hline$\left[\mathrm{C}_{8} \mathrm{H}_{10} \mathrm{O}+\mathrm{H}\right]^{+}$ & 123.081 & 2,4-/2,6-/3,5-dimethylphenol & oxygenated aromatic & 4.7 & 36 & 18 & 4.9 & 3.0 & $10 \pm 10$ \\
\hline$\left[\mathrm{C}_{7} \mathrm{H}_{8} \mathrm{O}_{2}+\mathrm{H}\right]^{+}$ & 125.060 & $\begin{array}{l}\text { 2-methoxyphenol } \\
\text { methylbenzenediols }\end{array}$ & oxygenated aromatic & 9.2 & 110 & 55 & 12 & 4.9 & $40 \pm 50$ \\
\hline$\left[\mathrm{C}_{6} \mathrm{H}_{6} \mathrm{O}_{3}+\mathrm{H}\right]^{+}$ & 127.040 & 5-(hydroxymethyl)furan-2-carbaldehyde & furan & 4.4 & 29 & 17 & 4.9 & 2.7 & $10 \pm 10$ \\
\hline$\left[\mathrm{C}_{10} \mathrm{H}_{8}+\mathrm{H}\right]^{+}$ & 129.070 & naphthalene & aromatic hydrocarbon & 42 & 20 & 80 & 100 & 33 & $60 \pm 30$ \\
\hline$\left[\mathrm{C}_{8} \mathrm{H}_{10} \mathrm{O}_{2}+\mathrm{H}\right]^{+}$ & 139.076 & $\begin{array}{l}\text { 2-methoxy-4-methylphenol } \\
\text { 4-(2-hydroxyethyl)phenol }\end{array}$ & oxygenated aromatic & 3.2 & 59 & 29 & 6.2 & 1.8 & $20 \pm 20$ \\
\hline$\left[\mathrm{C}_{11} \mathrm{H}_{10}+\mathrm{H}\right]^{+}$ & 143.086 & 1-/2-methylnaphthalene & aromatic hydrocarbon & 4.0 & 2.3 & 5.7 & 7.5 & 3.3 & $5 \pm 2$ \\
\hline$\left[\mathrm{C}_{9} \mathrm{H}_{6} \mathrm{O}_{2}+\mathrm{H}\right]^{+}$ & 147.045 & indene-1,3-dione & oxygenated aromatic & 11 & 13 & 13 & 11 & 6.0 & $11 \pm 3$ \\
\hline$\left[\mathrm{C}_{8} \mathrm{H}_{4} \mathrm{O}_{3}+\mathrm{H}\right]^{+}$ & 149.024 & phthalic anhydride $\mathrm{e}^{\mathrm{e}}$ & O-containing & 16 & 31 & 25 & 16 & 8.3 & $19 \pm 9$ \\
\hline$\left[\mathrm{C}_{8} \mathrm{H}_{8} \mathrm{O}_{3}+\mathrm{H}\right]^{+}$ & 153.055 & 4-hydroxy-3-methoxybenzaldehyde & oxygenated aromatic & 3.8 & 27 & 15 & 3.7 & 1.4 & $10 \pm 10$ \\
\hline$\left[\mathrm{C}_{12} \mathrm{H}_{8}+\mathrm{H}\right]^{+}$ & 153.070 & acenaphthylene & aromatic hydrocarbon & 6.1 & 3.6 & 12 & 15 & 8.3 & $9 \pm 5$ \\
\hline
\end{tabular}


Table 2. Continued.

\begin{tabular}{|c|c|c|c|c|c|c|c|c|c|}
\hline \multirow[t]{2}{*}{ Species } & \multirow{2}{*}{$\begin{array}{r}\text { Monoisotopic } \\
\qquad m / z\end{array}$} & \multirow[t]{2}{*}{ Structural assignment ${ }^{\mathrm{c}}$} & \multirow[t]{2}{*}{ Functional group } & \multicolumn{5}{|c|}{ Experiment } & \multirow[t]{2}{*}{ Average $^{\mathrm{d}}$} \\
\hline & & & & 1 & 2 & 3 & 4 & 5 & \\
\hline$\left[\mathrm{C}_{9} \mathrm{H}_{12} \mathrm{O}_{2}+\mathrm{H}\right]^{+}$ & 153.092 & $\begin{array}{l}\text { 4-ethyl-2-methoxyphenol } \\
\text { 1,2-dimethoxy-4-methylbenzene }\end{array}$ & oxygenated aromatic & 1.4 & 30 & 14 & 3.2 & BDL & $10 \pm 10$ \\
\hline$\left[\mathrm{C}_{8} \mathrm{H}_{10} \mathrm{O}_{3}+\mathrm{H}\right]^{+}$ & 155.071 & 2,6-dimethoxyphenol & oxygenated aromatic & 2.2 & 73 & 35 & 7.8 & 1.0 & $20 \pm 30$ \\
\hline$\left[\mathrm{C}_{12} \mathrm{H}_{10}+\mathrm{H}\right]^{+}$ & 155.086 & $\begin{array}{l}\text { 1,1'-biphenyl } \\
\text { 1,2-dihydroacenaphthylene }\end{array}$ & aromatic hydrocarbon & 3.1 & BDL & 4.3 & 6.1 & 2.9 & $3 \pm 2$ \\
\hline$\left[\mathrm{C}_{12} \mathrm{H}_{12}+\mathrm{H}\right]^{+}$ & 157.102 & dimethylnaphthalene & aromatic hydrocarbon & 1.3 & 3.0 & 3.2 & 2.2 & 1.2 & $2.2 \pm 0.9$ \\
\hline$\left[\mathrm{C}_{10} \mathrm{H}_{12} \mathrm{O}_{2}+\mathrm{H}\right]^{+}$ & 165.092 & $\begin{array}{l}\text { 2-methoxy-4-[(E)-prop-1-enyl]phenol } \\
\text { 2-methoxy-4-prop-2-enylphenol } \\
\text { 2-methoxy-4-[(Z)-prop-1-enyl]phenol }\end{array}$ & oxygenated aromatic & 0.92 & 24 & 13 & 2.3 & 0.59 & $8 \pm 10$ \\
\hline$\left[\mathrm{C}_{9} \mathrm{H}_{10} \mathrm{O}_{3}+\mathrm{H}\right]^{+}$ & 167.071 & $\begin{array}{l}\text { 1-(4-hydroxy-3-methoxyphenyl)ethanone } \\
\text { 2,5-dimethylbenzaldehyde } \\
\text { 3,4-dimethoxybenzaldehyde }\end{array}$ & oxygenated aromatic & 2.5 & 11 & 6.7 & 2.2 & 1.2 & $5 \pm 4$ \\
\hline$\left[\mathrm{C}_{13} \mathrm{H}_{10}+\mathrm{H}\right]^{+}$ & 167.086 & fluorene & aromatic hydrocarbon & BDL & BDL & 1.0 & 2.5 & 2.0 & $1 \pm 1$ \\
\hline$\left.\left[\mathrm{C}_{10} \mathrm{H}_{14} \mathrm{O}_{2}+\mathrm{H}\right]^{+}\right)$ & 167.107 & 2-methoxy-4-propylphenol & oxygenated aromatic & 0.88 & 7.6 & 4.4 & 1.1 & BDL & $3 \pm 3$ \\
\hline$\left[\mathrm{C}_{9} \mathrm{H}_{12} \mathrm{O}_{3}+\mathrm{H}\right]^{+}$ & 169.086 & 2,6-dimethoxy-4-methylphenol & oxygenated aromatic & BDL & 14 & 6.2 & 1.1 & BDL & $4 \pm 6$ \\
\hline$\left[\mathrm{C}_{14} \mathrm{H}_{10}+\mathrm{H}\right]^{+}$ & 179.086 & $\begin{array}{l}\text { phenanthrene } \\
\text { anthracene }\end{array}$ & aromatic hydrocarbon & 6.4 & 8.4 & 6.1 & 3.6 & 7.7 & $6 \pm 2$ \\
\hline$\left[\mathrm{C}_{13} \mathrm{H}_{8} \mathrm{O}+\mathrm{H}\right]^{+}$ & 181.065 & $\begin{array}{l}\text { fluoren-9-one } \\
\text { phenalen-1-one }\end{array}$ & oxygenated aromatic & 2.7 & 4.0 & 2.7 & 1.2 & 1.9 & $2 \pm 1$ \\
\hline$\left[\mathrm{C}_{10} \mathrm{H}_{12} \mathrm{O}_{3}+\mathrm{H}\right]^{+}$ & 181.086 & 1-(4-hydroxy-3-methoxyphenyl)propan-2-one & oxygenated aromatic & BDL & 4.2 & 2.6 & 1.1 & 0.69 & $2 \pm 2$ \\
\hline$\left[\mathrm{C}_{9} \mathrm{H}_{10} \mathrm{O}_{4}+\mathrm{H}\right]^{+}$ & 183.066 & $\begin{array}{l}\text { 3,4-dimethoxybenzoic acid } \\
\text { 4-hydroxy-3,5-dimethoxybenzaldehyde }\end{array}$ & oxygenated aromatic & 1.1 & BDL & 1.4 & 1.1 & 1.0 & $0.9 \pm 0.5$ \\
\hline$\left[\mathrm{C}_{10} \mathrm{H}_{14} \mathrm{O}_{3}+\mathrm{H}\right]^{+}$ & 183.102 & 4-ethyl-2,6-dimethoxyphenol & oxygenated aromatic & 1.0 & 7.4 & 4.2 & 1.0 & BDL & $3 \pm 3$ \\
\hline$\left[\mathrm{C}_{15} \mathrm{H}_{12}+\mathrm{H}\right]^{+}$ & 193.102 & $\begin{array}{l}\text { 1-/2-/3-/9-methylphenanthrene } \\
\text { 2-methylanthracene }\end{array}$ & aromatic hydrocarbon & 0.50 & 2.6 & 1.3 & $\mathrm{BDL}$ & 0.44 & $1 \pm 1$ \\
\hline$\left[\mathrm{C}_{11} \mathrm{H}_{14} \mathrm{O}_{3}+\mathrm{H}\right]^{+}$ & 195.102 & $\begin{array}{l}\text { 1,3-dimethoxy-2-prop-2-enoxybenzene } \\
\text { 2,6-dimethoxy-4-[(Z)-prop-1-enyl]phenol }\end{array}$ & oxygenated aromatic & BDL & 1.7 & 1.2 & BDL & BDL & $0.6 \pm 0.8$ \\
\hline$\left[\mathrm{C}_{16} \mathrm{H}_{10}+\mathrm{H}\right]^{+}$ & 203.086 & $\begin{array}{l}\text { fluoranthene } \\
\text { pyrene } \\
\text { acephenanthrylene }\end{array}$ & aromatic hydrocarbon & BDL & 0.87 & BDL & BDL & BDL & $0.2 \pm 0.4$ \\
\hline
\end{tabular}

$\mathrm{CO}_{2}, \mathrm{CO}$ and $\mathrm{CH}_{4}$ are measured using cavity ring down spectroscopy and all other species are measured using the PTR-ToF-MS. ${ }^{\mathrm{b}}$ BDL indicates value is below the detection limit. ${ }^{\mathrm{c}}$ Multiple structural assignments for a given ion correspond to possible isomers. ${ }^{\mathrm{d}}$ Uncertainties correspond to one sample standard deviation of the replicates. ${ }^{\mathrm{e}}$ Structural assignment based on known products produced during oxidation of aromatics (Bandow et al., 1985; Chan et al., 2009; Praplan et al., 2014).

Although a large fraction of atmospherically relevant organic gases are measured using the PTR-ToF-MS, some species are not quantitatively detected, including those with a proton affinity less than water (i.e., small alkanes). Based on previous studies of residential burning, alkanes are estimated to contribute less than $\sim 5 \%$ to the NMOG mass of either hard or soft wood and the sum of alkenes and alkynes, some of which are quantifiable with the PTR-ToF-MS, are estimated to contribute less than $\sim 15 \%$ to the total measured NMOG mass (McDonald et al., 2000; Schauer et al., 2001).

Figure 1 shows the primary NMOG mass spectrum for each experiment classified by NMOG functionality and the fractional contribution of NMOG functional groups to the total NMOG mass. EFs for individual compounds are presented in Table 2. For ease of reading, nominal $m / z$ is presented in the text and figures; however, monoisotopic $m / z$ for all identified species can be found in Tables 2 and S3. Separation of isobaric species is possible using the PTR-ToFMS, although isomers remain indistinguishable. Quantities of gas-phase species generated during residential wood combustion depend on a variety of parameters, such as type of burner and wood species. However, many compounds are commonly emitted and structures are assigned to observed ions based on previously identified species (McDonald et al., 2000; Schauer et al., 2001; Hedberg et al., 2002; Jordan and Seen, 2005; Pettersson et al., 2011; Evtyugina et al., 2014; Reda et al., 2015). A few small, unambiguous ions are also assigned a structure, including methanol, formic acid and acetonitrile. Approximately $70 \%$ of the total NMOG mass measured using the PTR-ToF-MS is assigned a structure based on this method.

NMOGs are categorized by functional groups including oxygenated, total $\mathrm{C}_{x} \mathrm{H}_{y}$, nitrogen-containing and other. Oxygenated subcategories include the following: acids (comprised of non-aromatic acids), carbonyls (comprised of nonaromatic carbonyls), oxygenated aromatics (not including furans), furans, O-containing (comprised of structurally unassigned oxygenated compounds and multifunctional oxygenated compounds) and $\mathrm{O}$ - and $\mathrm{N}$-containing (comprised of species containing both oxygen and nitrogen atoms). Species categorized as $\mathrm{N}$-containing contain no oxygen atoms. Total $\mathrm{C}_{x} \mathrm{H}_{y}$ subcategories include: aromatic hydrocarbons, and non-aromatic and structurally unassigned species (referred to as $\mathrm{C}_{x} \mathrm{H}_{y}$ in the text and figures). Higher molecular weight species lacking an ion assignment are categorized as "other". In the case of possible isomers, ions are categorized according to the species most likely to dominate based on previous 

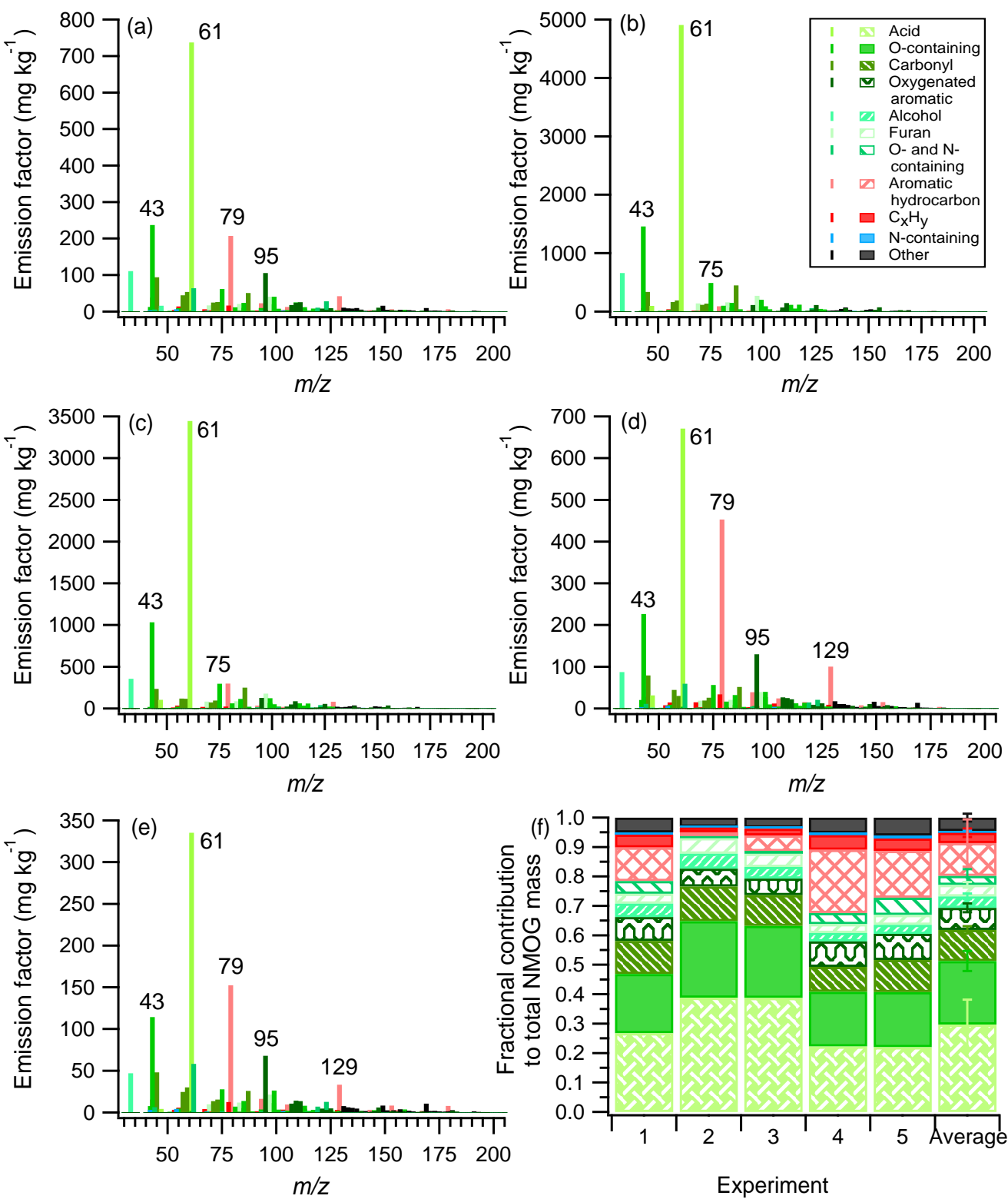

Figure 1. Mass spectra of primary NMOG emissions for experiments 1-5 (a-e) colored by functional group. (a-e) Labeled peaks correspond to $\left[\mathrm{C}_{2} \mathrm{H}_{3} \mathrm{O}\right]^{+}\left(m / z 43\right.$, fragment from higher molecular weight compounds), $\left[\mathrm{C}_{2} \mathrm{H}_{4} \mathrm{O}_{2}+\mathrm{H}\right]^{+}(m / z 61$, acetic acid $),\left[\mathrm{C}_{3} \mathrm{H}_{6} \mathrm{O}_{2}+\mathrm{H}\right]^{+}(m / z 75$, methyl acetate), $\left[\mathrm{C}_{6} \mathrm{H}_{6}+\mathrm{H}\right]^{+}\left(\mathrm{m} / z 79\right.$, benzene), $\left[\mathrm{C}_{6} \mathrm{H}_{6} \mathrm{O}+\mathrm{H}\right]^{+}\left(\mathrm{m} / z\right.$ 95, phenol) and $\left[\mathrm{C}_{10} \mathrm{H}_{8}+\mathrm{H}\right]^{+}(\mathrm{m} / z$, 129, naphthalene). The bars in (f) correspond to the fractional contribution of each functional group to the total NMOG mass for each experiment and the average of all experiments. Error bars correspond to one sample standard deviation of the replicates. Legend in (b) applies to (a)-(f).

studies (McDonald et al., 2000; Schauer et al., 2001; Hedberg et al., 2002; Jordan and Seen, 2005; Pettersson et al., 2011; Evtyugina et al., 2014; Reda et al., 2015).

Oxygenated species contribute $\sim 68-94 \%$ to the total primary NMOG mass, which has important atmospheric implications due to the role of these compounds in photochemical reactions, for example by altering $\mathrm{O}_{3}$ and peroxide formation (Mason et al., 2001; Shao et al., 2009). McDonald et al. (2000) and Schauer et al. (2001) previously ob- served the dominance of oxygenated NMOGs during residential burning of other wood types, whereas Evtyugina et al. (2014) found that benzene and benzene derivatives contributed $59 \%$ to the total measured NMOGs, compared to only $26 \%$ from oxygenated compounds for residential burning of beech wood in a woodstove. However, Evtyugina et al. (2014), as well as McDonald et al. (2000) and Schauer et al. (2001), did not include emissions from all lower molecular weight NMOGs, such as acetic acid. Oxygenated NMOGs 
are also reported as a large fraction of NMOGs emitted during open burning of many biomass fuels (Gilman et al., 2015; Stockwell et al., 2015).

Acids are the most abundant subclass of species in all experiments with an average $\mathrm{EF}$ of $2000 \pm 2000 \mathrm{mg} \mathrm{kg}^{-1}$, and acetic acid $\left(\left[\mathrm{C}_{2} \mathrm{H}_{4} \mathrm{O}_{2}+\mathrm{H}\right]^{+}\right.$at nominal $\left.\mathrm{m} / z 61\right)$ is the most highly emitted compound in all experiments. In addition to acetic acid, $\left[\mathrm{C}_{2} \mathrm{H}_{4} \mathrm{O}_{2}+\mathrm{H}\right]^{+}$can correspond to glycolaldehyde; however, Stockwell et al. (2015) found that acetic acid contributes $\sim 75-93 \%$ to $\left[\mathrm{C}_{2} \mathrm{H}_{4} \mathrm{O}_{2}+\mathrm{H}\right]^{+}$during open burning of black spruce (Picea mariana) and ponderosa pine (Pinus ponderosa) and thus, it is expected that this ion is also largely attributable to acetic acid in the current study. Acetic acid and formic acid $\left(\left[\mathrm{CH}_{2} \mathrm{O}_{2}+\mathrm{H}\right]^{+}\right.$at nominal $m / z 47)$ are the most abundant carboxylic acids in the atmosphere and are important contributors to atmospheric acidity (Chebbi and Carlier, 1996). However, the sources of these acids are poorly understood (Paulot et al., 2011) and data on their EFs from residential wood combustion are relatively unknown. The high acetic acid EFs found here indicate that residential wood combustion can be an important local source of this acid. Interestingly, the enhancement of acetic acid $\left(\Delta \mathrm{C}_{2} \mathrm{H}_{4} \mathrm{O}_{2}\right)$ over background levels relative to $\mathrm{CO}$ enhancement $(\triangle \mathrm{CO})$ in the current study ranges from $\sim 6$ to $80 \mathrm{pptv} p p b v^{-1}$ (Table 1), which is much higher than the average $0.58 \mathrm{pptv} \mathrm{ppbv}^{-1}$ (sum of gas and aerosol phase) measured in an Alpine valley heavily impacted by residential wood combustion in winter (Gaeggeler et al., 2008). Further work is needed to investigate the source of this discrepancy, as limited ambient measurements are available from regions heavily impacted by residential wood combustion. However, it is possible that the ambient measurements were dominated by emissions produced during poor burning conditions (e.g., starting phase) where $\mathrm{CO}$ EFs are expected to be higher than during the stable burning phase investigated in the current study.

The sum of oxygenated and non-oxygenated aromatic compounds contribute $\sim 7-30 \%\left(800 \pm 300 \mathrm{mg} \mathrm{kg}^{-1}\right)$ to the total primary NMOG mass with benzene $\left(\left[\mathrm{C}_{6} \mathrm{H}_{6}+\mathrm{H}\right]^{+}\right.$at nominal $m / z 79)$, phenol $\left(\left[\mathrm{C}_{6} \mathrm{H}_{6} \mathrm{O}+\mathrm{H}\right]^{+}\right.$at nominal $\left.m / z 95\right)$, and naphthalene $\left(\left[\mathrm{C}_{10} \mathrm{H}_{8}+\mathrm{H}\right]^{+}\right.$at nominal $\mathrm{m} / z$ 129) as the three most dominant species. Oxidation products of aromatic species are the largest contributors to residential wood combustion SOA in this study (Bruns et al., 2016) and both aromatic and related oxidation products are of interest due to their particularly deleterious effects on health (Fu et al., 2012).

For the other functional group categories, carbonyl and alcohols contribute $\sim 8-12 \%\left(600 \pm 600 \mathrm{mg} \mathrm{kg}^{-1}\right)$ and $\sim 3-$ $5 \%\left(300 \pm 300 \mathrm{mg} \mathrm{kg}^{-1}\right)$, respectively, to the total NMOG mass. In general, the most highly emitted carbonyl compound is acetaldehyde $\left(\left[\mathrm{C}_{2} \mathrm{H}_{4} \mathrm{O}+\mathrm{H}\right]^{+}\right.$at nominal $\left.\mathrm{m} / z 45\right)$. Methanol $\left(\left[\mathrm{CH}_{3} \mathrm{OH}+\mathrm{H}\right]^{+}\right.$at nominal $\left.m / z 33\right)$ is the most highly emitted alcohol, although other acyclic alcohols can undergo extensive fragmentation in the mass spectrometer.

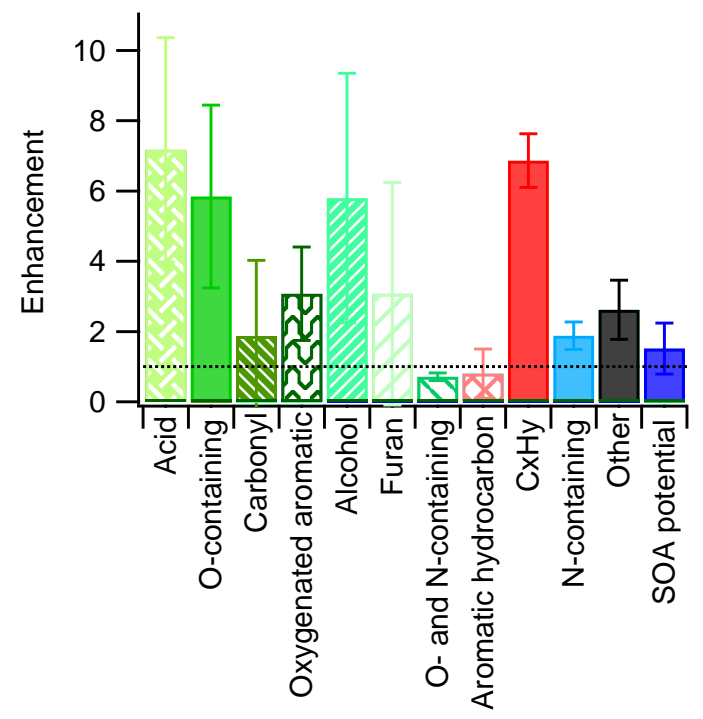

Figure 2. Enhancement (average value $\left(\mathrm{mg} \mathrm{kg}^{-1}\right)$ of experiments 2 and 3 relative to the average value of experiments 1,4 and 5) in each NMOG functional group category and for SOA formation potential. Total SOA formation potential is determined using the primary EF of each NMOG identified as a SOA precursor and literature SOA yields and assumes complete consumption of each NMOG with aging (see text for details). Error bars correspond to one sample standard deviation.

Furans are only a minor contributor to the total primary NMOG mass, contributing $\sim 3-5 \%\left(300 \pm 300 \mathrm{mg} \mathrm{kg}^{-1}\right)$, but are of potential interest as several furans were recently identified as SOA precursors (Gómez Alvarez et al., 2009) and possible open biomass burning markers (Gilman et al., 2015).

\subsection{Burn variability}

Although the same compounds are emitted during all burns, there is variability in EFs between experiments despite efforts to replicate burns as closely as possible and the fact that the MCE for each experiment falls within a narrow range (0.974-0.978; Table 1). Experiments 2 and 3 show marked differences in total NMOG EFs and NMOG composition compared to experiments 1,4 and 5. For example, the total NMOG EF is $\sim 9$ times higher in experiment 2 compared to experiment 5 (Table 2). Acetic acid EFs vary by a factor of $\sim 15$ between burns, with high emissions in experiments 2 and 3 relative to experiments 1,4 and 5 . The total emission of oxygenated species also correlates with acetic acid emissions, with total oxygenated EFs considerably higher in experiments 2 and 3 than in experiments 1,4 and 5. In contrast, aromatic hydrocarbons and $\mathrm{C}_{x} \mathrm{H}_{y}$ EFs show no correlation with total oxygenated species or acetic acid EFs. Interestingly, differences in black carbon EFs, primary organic aerosol EFs and primary organic aerosol mass to black car- 
bon ratios are also not observed between these two groupings of experiments $(2,3$ and $1,4,5)$, as presented previously (Bruns et al., 2016). Enhancements in the average EF for the different functional groups in experiments 2 and 3 relative to experiments 1, 4 and 5 are shown in Fig. 2.

The differences in EFs due to inter-burn variability illustrate the difficulty in constraining EFs from residential wood combustion. The burner is housed in an uninsulated building and the emission profile variability could be due to effects of outdoor temperature variability on the burner. For example, emission profiles from burning lignite and pyrolysis of bark and other biomass sources have been shown to vary with burn temperature (Hansson et al., 2004; Šyc et al., 2011). Further work to constrain the possible range of EFs generated under different conditions is critical for improving model inputs. EFs are also dependent on factors such as appliance type and fuel loading, and further work is needed to characterize the emissions and the evolution of these emissions with aging generated from burning of different wood types and under different burn parameters.

\subsection{Biomass burning tracers}

Individual compounds emitted exclusively or in large quantities during biomass burning are of interest for source apportionment, and compounds contributing to SOA formation are of particular interest for climate and health (Fig. 3). Acetonitrile is used as an ambient gas-phase marker for open biomass burning (de Gouw et al., 2003; Singh et al., 2003). In the current experiments, acetonitrile EFs are relatively low $\left(3.5 \pm 0.3 \mathrm{mg} \mathrm{kg}^{-1}\right)$ compared to open biomass burning ( 20-1000 $\mathrm{mg} \mathrm{kg}^{-1}$; Yokelson et al., 2008, 2009; Akagi et al., 2013; Stockwell et al., 2015). The enhancements of acetonitrile over background levels relative to $\mathrm{CO}$ enhancement, $\Delta \mathrm{CH}_{3} \mathrm{CN} / \Delta \mathrm{CO}$, are $\sim 0.08-0.1 \mathrm{pptv}_{\mathrm{ppbv}}{ }^{-1}$ (Table 1). This is slightly lower than the only previously published residential wood combustion measurements ( 0.1 to $0.8 \mathrm{pptv}_{\mathrm{ppbv}}{ }^{-1}$; Grieshop et al., 2009a), but is much lower than $\Delta \mathrm{CH}_{3} \mathrm{CN} / \triangle \mathrm{CO}$ measurements in ambient air masses impacted by open biomass burning $\left(\sim 1-2\right.$ pptv ppbv $\left.^{-1}\right)$ (Holzinger et al., 1999; Andreae and Merlet, 2001; Christian et al., 2003; de Gouw et al., 2003; Jost et al., 2003; Holzinger et al., 2005; de Gouw et al., 2006, 2009; Warneke et al., 2006; Yokelson et al., 2008, 2009; Aiken et al., 2010; Akagi et al., 2013). However, $\Delta \mathrm{CH}_{3} \mathrm{CN} / \Delta \mathrm{CO}$ during open burning has been shown to depend strongly on fuel type; Stockwell et al. (2015) observed $\Delta \mathrm{CH}_{3} \mathrm{CN} / \Delta \mathrm{CO}$ values from 0.0060 to $7.1 \mathrm{pptv} \mathrm{ppbv}^{-1}$ for individual open burns of different biomass types in the laboratory. In agreement with the current study, ambient measurements of acetonitrile made in Colorado (USA) were not associated with fresh residential burning emissions (Coggon et al., 2016). Lower ambient measurements of nitrogen-containing NMOGs (including acetonitrile) during residential burning compared to open burning were attributed to the generally lower nitrogen

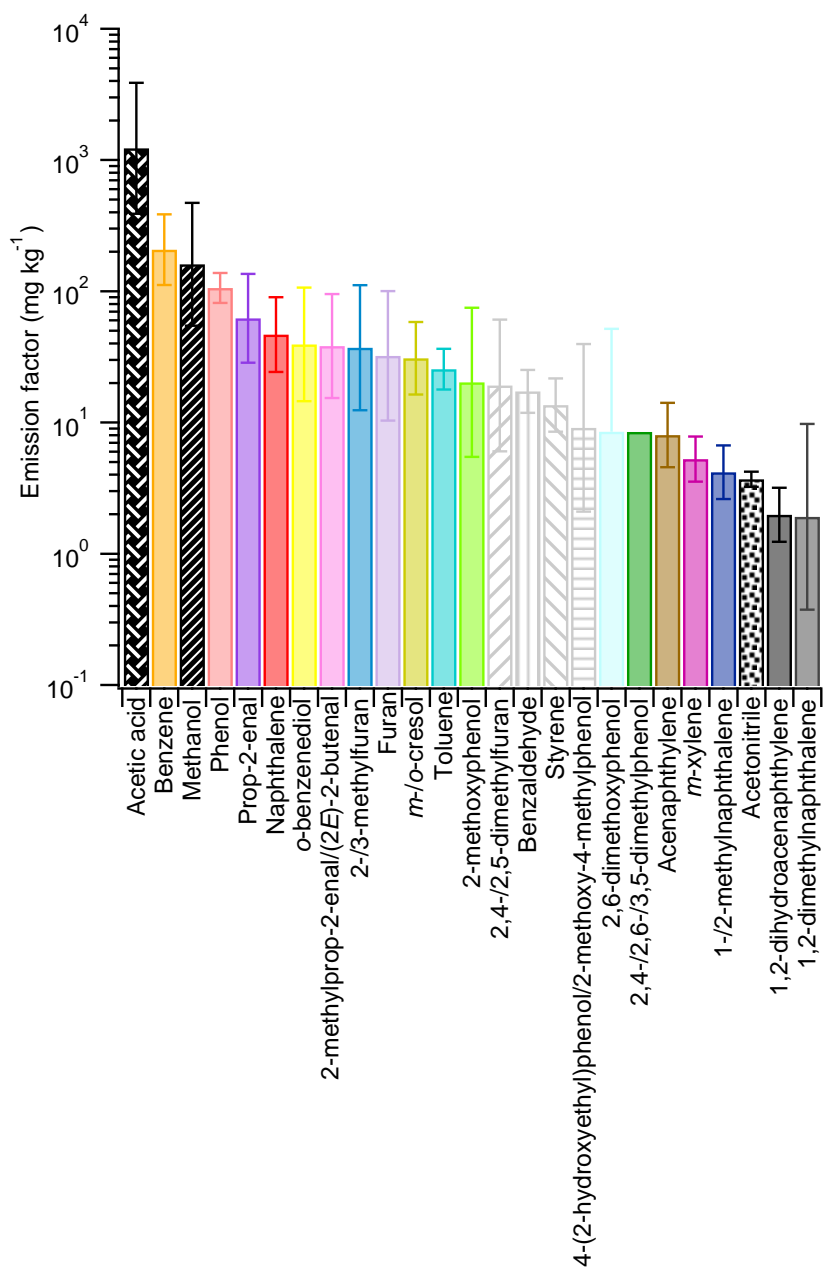

Figure 3. Geometric mean of the primary emission factors for gasphase species of particular interest for SOA formation (solid bars and gray patterned bars) and identification of air masses influenced by biomass burning (black patterned bars). Colors and patterns corresponding to NMOGs contributing to SOA formation are consistent with Bruns et al. (2016). Error bars correspond to the sample geometric standard deviation of the replicates.

content in fuels burned residentially (Coggon et al., 2016). Lower nitrogen content of the fuel is likely a contributor to the relatively low acetonitrile emissions in the current study.

The primary emission factors of other nitrogenated species, such as $\mathrm{C}_{3} \mathrm{H}_{3} \mathrm{~N}$ (likely corresponding to acrylonitrile) and $\mathrm{HNCO}$ ranged in our study from 3.6 to $6.4 \mathrm{mg} \mathrm{kg}^{-1}$ and BDL (below detection limit) to $11 \mathrm{mg} \mathrm{kg}^{-1}$, respectively. Emission factors of $\mathrm{C}_{3} \mathrm{H}_{3} \mathrm{~N}$ in the current study are lower than those observed during open burning (e.g., $\sim 10$ $90 \mathrm{mg} \mathrm{kg}^{-1}$; Akagi et al., 2013), as expected based on the lower acetonitrile emission factors observed in the current study and the findings of Coggon et al. (2016).

Further work is needed to investigate $\mathrm{CH}_{3} \mathrm{CN}$ emissions from residential burning of other wood types, as well as emissions during other burning phases (e.g., smoldering). How- 
ever, these low enhancements may be difficult to differentiate from ambient background levels, making acetonitrile a poor marker for residential wood combustion under these burning conditions. Coggon et al. (2016) concluded that acetonitrile may not be a good tracer for residential burning in urban areas.

The interference from isobaric compounds when quantifying acetonitrile using a PTR-MS is an important consideration when high-resolution data are not available. Previously, several studies have determined that this interference is minimal during open biomass burning (de Gouw et al., 2003; Warneke et al., 2003, 2011; Christian et al., 2004). Recently, Dunne et al. (2012) quantified interferences with acetonitrile measurements in polluted urban air using a quadrupole PTR-MS and found contributions of 5-41\% to $m / z 42$ from non-acetonitrile ions including $\left[\mathrm{C}_{3} \mathrm{H}_{6}\right]^{+}$and the ${ }^{13} \mathrm{C}$ isotope contribution from $\left[\mathrm{C}_{3} \mathrm{H}_{5}\right]^{+}$. In the current study, in addition to contributions from $\left[\mathrm{C}_{3} \mathrm{H}_{6}\right]^{+}$and the isotopic contribution from $\left[\mathrm{C}_{3} \mathrm{H}_{5}\right]^{+}, \sim 30-50 \%$ of the total signal at $\mathrm{m} / \mathrm{z} 42$ is due to $\left[\mathrm{C}_{2} \mathrm{H}_{2} \mathrm{O}\right]^{+}$, which is presumably a fragment from higher molecular weight species. The total contribution to $\mathrm{m} / \mathrm{z} 42$ from species besides acetonitrile is $\sim 70-85 \%$. Although an investigation into the effects of the PTR-MS operating conditions (e.g., $\left[\mathrm{O}_{2}\right]^{+}$signal from ion source, $E / N$ affecting fragmentation) is outside the scope of the current study, the possibility of considerable non-acetonitrile signal at $m / z 42$ should be taken into consideration when using nominal mass PTR-MS data to quantify acetonitrile from residential wood combustion.

Methanol is also used to identify air masses influenced by open biomass burning, and enhancement over background levels relative to $\mathrm{CO}$ enhancement $\left(\Delta \mathrm{CH}_{3} \mathrm{OH} / \Delta \mathrm{CO}\right)$ is typically $\sim 1-80 \mathrm{pptv} \mathrm{ppbv}^{-1}$ in ambient and laboratory measurements of fresh open biomass burning emissions (Holzinger et al., 1999; Goode et al., 2000; Andreae and Merlet, 2001; Christian et al., 2003; Yokelson et al., 2003; Singh et al., 2004; Tabazadeh et al., 2004; Holzinger et al., 2005; de Gouw et al., 2006; Gaeggeler et al., 2008; Yokelson et al., 2008, 2009; Akagi et al., 2013; Stockwell et al., 2015; Müller et al., 2016). Here, we find similar values ranging from $\sim 2$ to $20 \mathrm{pptv}_{\mathrm{ppbv}}{ }^{-1}$ (Table 1), in agreement with Gaeggeler et al. (2008) who measured a $\Delta \mathrm{CH}_{3} \mathrm{OH} / \Delta \mathrm{CO}$ value of $2.16 \mathrm{pptv}_{\mathrm{ppbv}}{ }^{-1}$ in an Alpine valley heavily impacted by residential wood combustion emissions in winter.

\subsection{Chamber studies of NMOG aging}

Previous investigations of aged residential wood combustion emissions have largely focused on the evolution of the aerosol phase (Grieshop et al., 2009a, b; Hennigan et al., 2010; Heringa et al., 2011; Bruns et al., 2015a, b, 2016) and little is known about the evolution of the gas phase. The evolution of the NMOG functional group categories with increasing $\mathrm{OH}$ exposure is shown in Fig. 4. Figure 5 shows the absolute change in mass spectral signal between the aged and primary NMOG quantities. Although an increase in NMOG mass could be expected with aging due to oxygenation, total NMOG mass decreases by $\sim 5-30 \%$

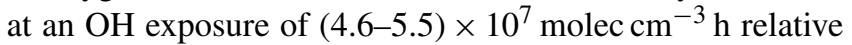
to the primary emissions in experiments $1-4$, likely due to the conversion of species from the gas to particle phase, the mass of which increased considerably with aging (Bruns et al., 2016), and the formation of gas-phase species not quantified here (e.g., formaldehyde). Previous investigation of these experiments determined that the conversion of NMOGs traditionally included in models to SOA accounts for only $\sim 3-27 \%$ of the observed SOA, whereas $\sim 84-116 \%$ of the SOA is explained by inclusion of non-traditional precursors, including naphthalene and phenol (Bruns et al., 2016). The total NMOG mass increases slightly, by $\sim 5 \%$, in experiment 5. Quantities of individual NMOGs and NMOG functional group categories, after reaching an $\mathrm{OH}$ exposure of (4.6-5.5) $\times 10^{7}$ molec $\mathrm{cm}^{-3} \mathrm{~h}$, are presented in Table S3. In addition to gas-to-particle phase partitioning and formation of gas-phase species not quantified here, a decrease in NMOG mass with aging could also be due to losses of gas-phase species to the chamber walls (Zhang et al., 2014; Bian et al., 2015). Measurements of NMOGs in the chamber prior to aging are stable, indicating that the chamber walls are not a sink for NMOGs, but rather that NMOGs are in equilibrium with the chamber walls, particles and the gas phase. Zhang et al. (2014) show that the rate of NMOG wall loss is inversely proportional to seed aerosol concentration and $\mathrm{OH}$ concentration, both of which are relatively high in the current experiments (Table $\mathrm{S} 1$; $\mathrm{OH}$ concentrations were $\sim 1.4 \times 10^{7}$ molec $\mathrm{cm}^{-3}$ ). Under these experimental conditions, NMOG wall losses are not expected to be large. Future studies are needed to investigate vapor wall loss of residential wood combustion emissions during aging.

Subcategories of oxygenated species behave differently with aging. For example, total quantities $\left(\mathrm{mg} \mathrm{kg}^{-1}\right)$ of oxygenated aromatic species decrease by factors of $\sim 7-15$ and furan quantities decrease by factors of $\sim 4-9$, whereas all other oxygenated subcategories, as well as $\mathrm{N}$-containing species, remain within a factor of 2 of primary values at an $\mathrm{OH}$ exposure of $(4.6-5.5) \times 10^{7}$ molec $\mathrm{cm}^{-3} \mathrm{~h}$. Aromatic hydrocarbons and $\mathrm{C}_{x} \mathrm{H}_{y}$ quantities decrease with aging by factors of $\sim 1.5-3$. The large decreases in oxygenated aromatic species and furans illustrate the highly reactive nature of these species with respect to $\mathrm{OH}$. The evolution of the bulk NMOG elemental composition during aging is shown in Fig. S2.

In all experiments, formic acid quantities increase considerably with aging (by factors of $\sim 5-50$ ), as do $\left[\mathrm{C}_{4} \mathrm{H}_{2} \mathrm{O}_{3}+\mathrm{H}\right]^{+}$quantities at nominal $\mathrm{m} / \mathrm{z} 99$ (by factors of $\sim 2-3$, and which likely corresponds to maleic anhydride), both of which are formed during the oxidation of aromatic species among other compounds (Bandow et al., 1985; Sato et al., 2007; Praplan et al., 2014). However, the fragment resulting from the loss of water from maleic acid cannot be dis- 

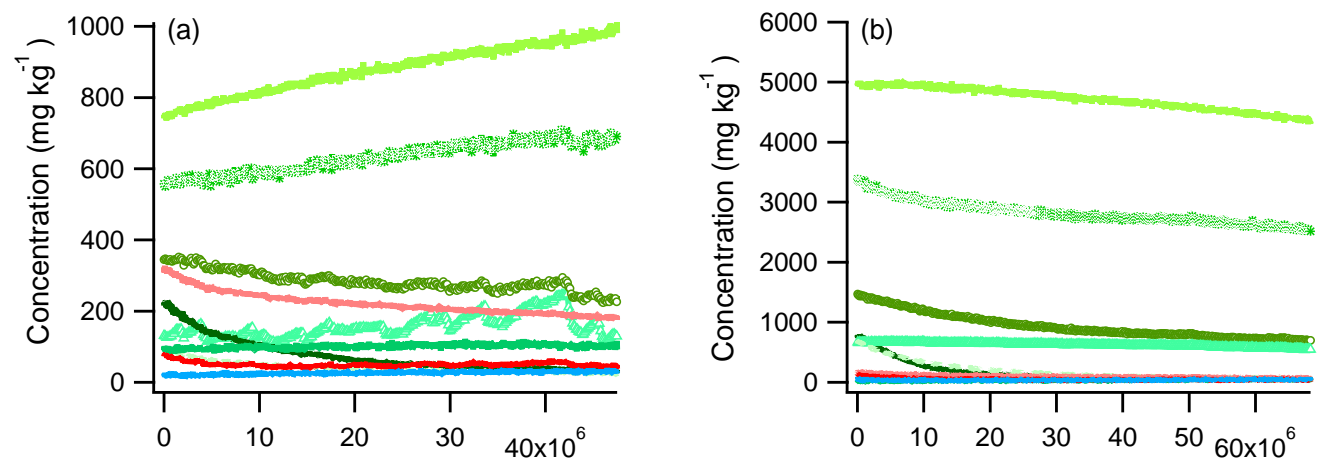

$\mathrm{OH}$ exposure $\left(\right.$ molec $\left.\mathrm{cm}^{-3} \mathrm{~h}\right)$
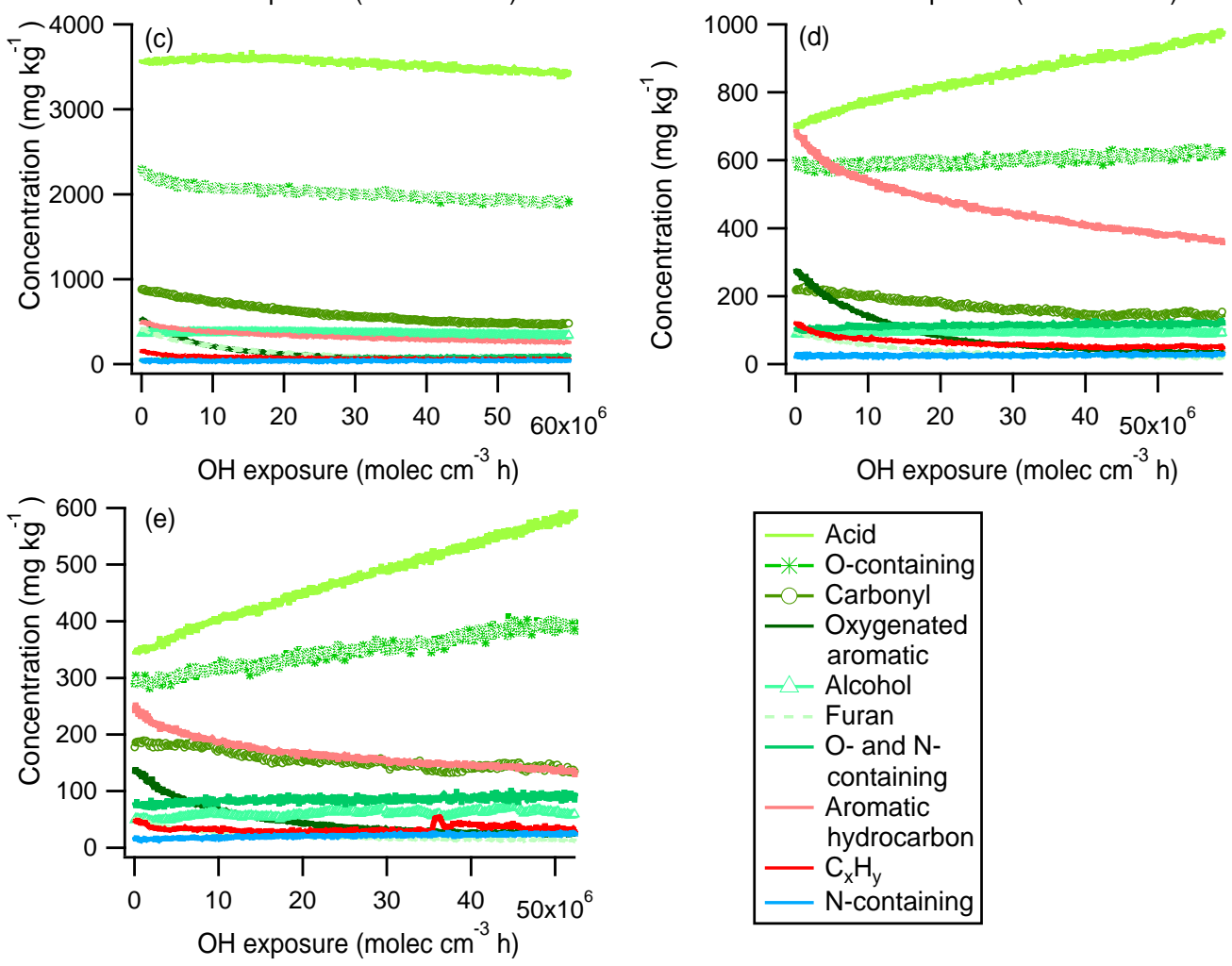

Figure 4. Temporal evolution of gas-phase species categorized by functional group throughout aging in the smog chamber for experiments 1-5 (a-e). Units on the $y$ axes are mass of each functional group $(\mathrm{mg})$ per mass of wood consumed $(\mathrm{kg})$.

tinguished from maleic anhydride using the PTR-ToF-MS. Formic acid is underestimated in models, likely due to missing secondary sources (Paulot et al., 2011), and these results indicate that aging of residential wood combustion emissions can result in considerable secondary formic acid production. The signal at $m / z 149$, corresponding to $\left[\mathrm{C}_{8} \mathrm{H}_{4} \mathrm{O}_{3}+\mathrm{H}\right]^{+}$, increases by factors of $\sim 2-7$ with aging. This ion likely corresponds to phthalic anhydride, which is a known naphthalene oxidation product (Chan et al., 2009).

Acetic acid formation has been observed in some ambient, open biomass burning plumes with aging (Goode et al., 2000; Hobbs et al., 2003; Yokelson et al., 2003), whereas it has not in others (de Gouw et al., 2006), and a doubling of $m / z 61$, likely dominated by acetic acid, was observed during aging of residential burning emissions in a previous laboratory study (Grieshop et al., 2009a). In the current study, no increase in the average acetic acid concentration relative to $\mathrm{CO}_{(g)}$ is observed (Table 1). Note that this implies production of secondary acetic acid that compensates for the expected consumption of $\sim 8-10 \%$ of primary acetic acid by reaction with $\mathrm{OH}$ at an $\mathrm{OH}$ exposure of (4.5$5.5) \times 10^{7}$ molec $\mathrm{cm}^{-3} \mathrm{~h}$. These results indicate that acetic acid from residential burning of beech wood is dominated by primary emissions of this species (Table 1). As with acetic acid, there are discrepancies in methanol behavior as open biomass burning plumes undergo aging (Goode et al., 2000; 

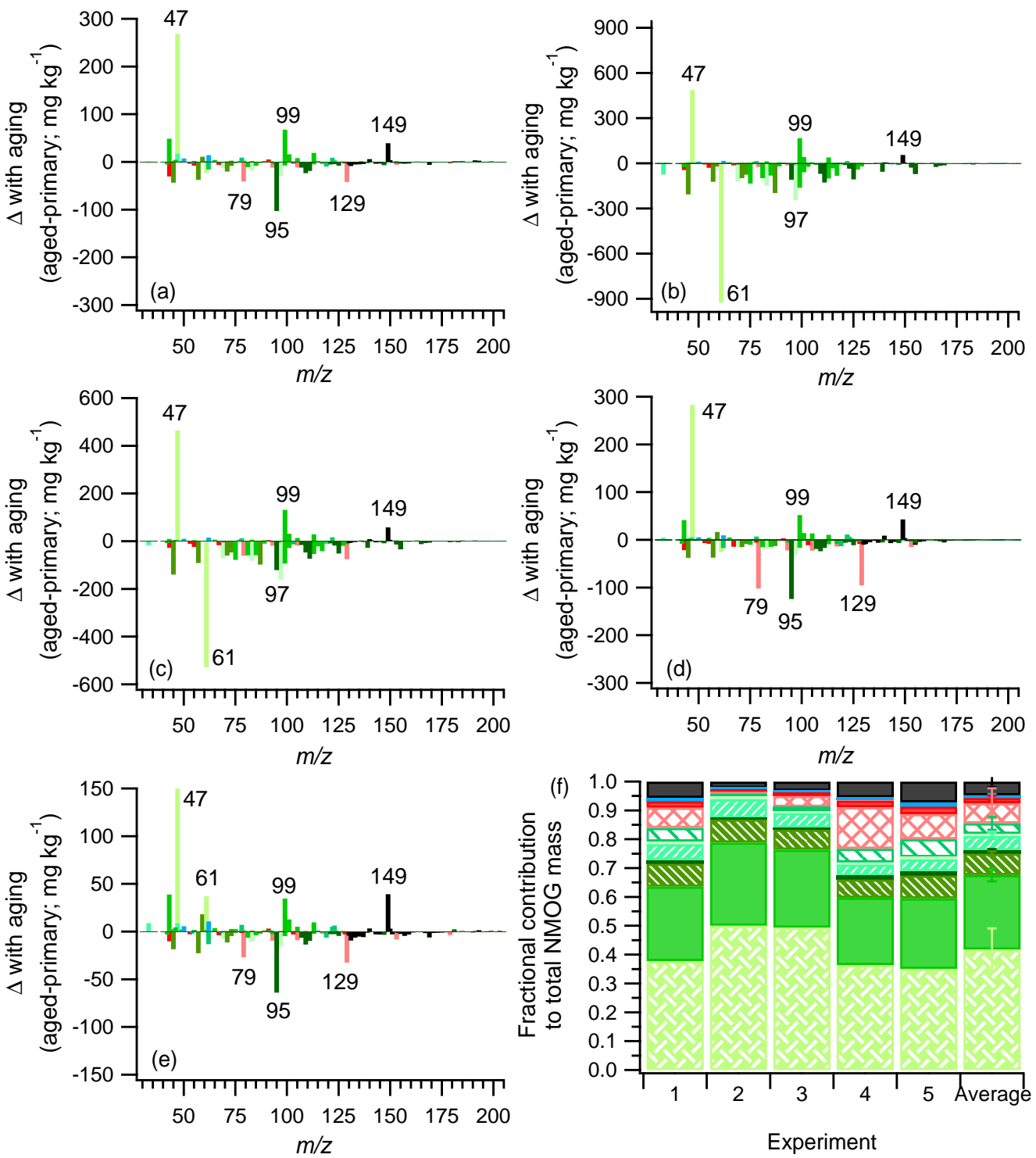

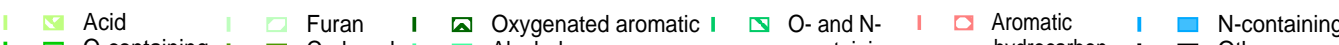

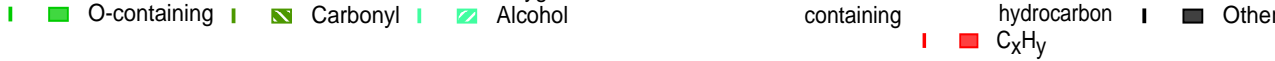

Figure 5. Absolute difference of aged and primary mass spectra for experiments 1-5 (a-e), where peaks less than zero decrease during aging and peaks greater than zero increase during aging. Aged emissions correspond to an $\mathrm{OH}$ exposure of $(4.5-5.5) \times 10^{7} \mathrm{molec}^{-3} \mathrm{~h}$. (a-e) Labeled peaks correspond to $\left[\mathrm{CH}_{2} \mathrm{O}_{2}+\mathrm{H}\right]^{+}(\mathrm{m} / \mathrm{z} 47$, formic acid $),\left[\mathrm{C}_{2} \mathrm{H}_{4} \mathrm{O}_{2}+\mathrm{H}\right]^{+}(m / z 61$, acetic acid $),\left[\mathrm{C}_{6} \mathrm{H}_{6}+\mathrm{H}\right]^{+}(m / z 79$, benzene), $\left[\mathrm{C}_{6} \mathrm{H}_{6} \mathrm{O}+\mathrm{H}\right]^{+}\left(\mathrm{m} / z\right.$, 95, phenol), $\left[\mathrm{C}_{5} \mathrm{H}_{4} \mathrm{O}_{2}+\mathrm{H}\right]^{+}\left(\mathrm{m} / z\right.$, 97, furan-2-carbaldehyde), $\left[\mathrm{C}_{4} \mathrm{H}_{2} \mathrm{O}_{3}+\mathrm{H}\right]^{+}(\mathrm{m} / z$, 99, maleic anhydride), $\left[\mathrm{C}_{10} \mathrm{H}_{8}+\mathrm{H}\right]^{+}(\mathrm{m} / \mathrm{z}, 129$, naphthalene $)$ and $\left[\mathrm{C}_{8} \mathrm{H}_{4} \mathrm{O}_{3}+\mathrm{H}\right]^{+}(\mathrm{m} / z, 149$, phthalic anhydride). The bars in (f) correspond to the fractional contribution of each category to the total NMOG EF at an $\mathrm{OH}$ exposure of $(4.5-5.5) \times 10^{7} \mathrm{molec} \mathrm{cm}^{-3} \mathrm{~h}$ for each experiment and the average of all experiments. Error bars correspond to one sample standard deviation of the replicates.

Yokelson et al., 2003; Tabazadeh et al., 2004; Holzinger et al., 2005; de Gouw et al., 2006; Akagi et al., 2013). As described by Akagi et al. (2013), methanol enhancement has been hypothesized to correlate with terpene concentration and here, methanol remains within $\sim 1-20 \%$ of the primary value after exposure to $(4.5-5.5) \times 10^{7}$ molec cm $\mathrm{cm}^{-3} \mathrm{~h}$
$\mathrm{OH}$ (Table 1), which is expected based on the reaction with OH (Overend and Paraskevopoulos, 1978) and the low terpene concentrations. Monoterpene concentrations are below the detection limit in all experiments and isoprene emissions are relatively low (Table 2 ). 
We have previously identified the compounds contributing to the majority of the SOA formed during these experiments (Bruns et al., 2016). The average EF for each of these species is shown in Fig. 3. Figure S3 shows the observed decay of the SOA precursors contributing the most to SOA formation during aging in the chamber, compared to the expected decay based on the $\mathrm{OH}$ concentration in the chamber and the reaction rate with respect to $\mathrm{OH}$. There is generally good agreement between the observed and calculated decay for each compound which supports the structural assignment of each ion. For 2-methoxyphenol and 2,6-dimethoxyphenol (Fig. S3f and i, respectively), the agreement between the observed and calculated decays is not as good as for the other compounds, with slower decays than predicted. This discrepancy may be due to fragmentation of related compounds to form 2-methoxyphenol and 2,6-dimethoxyphenol in the instrument or formation of these compounds in the chamber during oxidation. For $o$-benzenediol, the decays are initially faster than expected and then become slower with increased aging, possibly due to the presence of isomers with different reaction rates with respect to $\mathrm{OH}$.

\subsection{Aged emission variability}

As described above, the primary emission profiles, as well as total NMOG mass emitted, vary considerably for experiments 2 and 3 compared to experiments 1, 4 and 5, with much higher total NMOG emissions in experiments 2 and 3. It is expected that the aged emission profiles also exhibit variability based on the primary emissions. Total acid and Ocontaining species decrease with aging in experiments 2 and 3 , in contrast to experiments 1,4 and 5, where these classes increase with aging (Fig. 4). Formic acid shows the largest increase with aging in all experiments $\left(\sim 190-480 \mathrm{mg} \mathrm{kg}^{-1}\right.$ relative to the primary EF, Fig. 5), however, in experiments 1,4 and 5 , this increase contributes much more to the total acid mass as the total acid mass is $\sim 5-15$ times lower compared to experiments 2 and 3 . An analogous case occurs for maleic anhydride for the O-containing class of compounds. As formic acid and maleic anhydride are formed from the oxidation of aromatic compounds (Bandow et al., 1985; Sato et al., 2007; Praplan et al., 2014), among others, a higher fraction of aromatic species to the total NMOG emissions will contribute to increases in acid and O-containing NMOGs. Inclusion of NMOGs not quantified by PTR-ToF-MS could impact the trends observed in Fig. 4.

To determine the impact of the high NMOG emission experiments ( 2 and 3 ) compared to the lower NMOG emission experiments (1, 4 and 5) on SOA formation potential, individual SOA precursors with published SOA yields are investigated. The SOA formation potential for each of these 18 compounds is determined as the product of the primary $\mathrm{EF}$ and the best-estimate SOA yield determined from the literature, as determined previously (Bruns et al., 2016). The total SOA formation potential for each experiment is taken as the sum of the individual SOA formation potentials. Interestingly, the SOA formation potential is similar in all experiments and the average enhancement of SOA formation potential in experiments 2 and 3 compared to the average of experiments 1, 4 and 5 is insignificant (Fig. 2), despite the considerably different total NMOG EFs.

\section{Conclusions}

This study is the first detailed characterization of primary NMOGs from residential wood combustion using a PTRToF-MS and the first investigation of the evolution of the majority of these NMOGs with aging. Differences in EFs and profiles between residential burning and open burning can be considerable and these results illustrate the importance of considering these emission sources individually. While total emissions from open burning are much larger than from residential burning, the societal relevance of residential wood burning emissions is nontrivial. A large fraction of open biomass burning derives from wildfires in sparsely populated regions (Ito and Penner, 2004), whereas residential wood combustion has been shown to be a major fraction of wintertime submicron organic aerosol in densely populated communities (Glasius et al., 2006; Krecl et al., 2008; Gonçalves et al., 2012; Guofeng et al., 2012; Crippa et al., 2013; Herich et al., 2014; Tao et al., 2014; Paraskevopoulou et al., 2015). Interestingly, MCE does not completely capture inter-burn variability, which is driven by differences in oxygenated content. This work clearly shows that measurements of total NMOGs or total hydrocarbon measurements are insufficient for estimating SOA formation potential from residential wood combustion. While this work characterizes the stable burning of beech wood in a modern woodstove, the composition and quantities of wood combustion emissions are highly dependent on many factors, and further work is needed to characterize the emissions and the evolution of these emissions with aging generated from burning of different wood types and under different burn parameters.

\section{Data availability}

The datasets are available upon request to the corresponding authors.

\section{The Supplement related to this article is available online at doi:10.5194/acp-17-705-2017-supplement.}

Acknowledgement. The research leading to these results received funding from the European Community's Seventh Framework Programme (FP7/2007-2013) under grant agreement no. 290605 (PSI-FELLOW), from the Competence Center Environment and 
Sustainability (CCES) (project OPTIWARES) and from the Swiss National Science Foundation (WOOSHI grant 140590 and starting grant BSSGI0_155846). We are grateful to René Richter for technical assistance and to Mike Cubison for analysis support.

Edited by: E. Browne

Reviewed by: two anonymous referees

\section{References}

Aiken, A. C., de Foy, B., Wiedinmyer, C., DeCarlo, P. F., Ulbrich, I. M., Wehrli, M. N., Szidat, S., Prevot, A. S. H., Noda, J., Wacker, L., Volkamer, R., Fortner, E., Wang, J., Laskin, A., Shutthanandan, V., Zheng, J., Zhang, R., Paredes-Miranda, G., Arnott, W. P., Molina, L. T., Sosa, G., Querol, X., and Jimenez, J. L.: Mexico city aerosol analysis during MILAGRO using high resolution aerosol mass spectrometry at the urban supersite (T0) Part 2: Analysis of the biomass burning contribution and the non-fossil carbon fraction, Atmos. Chem. Phys., 10, 5315-5341, doi:10.5194/acp-10-5315-2010, 2010.

Akagi, S. K., Yokelson, R. J., Burling, I. R., Meinardi, S., Simpson, I., Blake, D. R., McMeeking, G. R., Sullivan, A., Lee, T., Kreidenweis, S., Urbanski, S., Reardon, J., Griffith, D. W. T., Johnson, T. J., and Weise, D. R.: Measurements of reactive trace gases and variable $\mathrm{O} 3$ formation rates in some South Carolina biomass burning plumes, Atmos. Chem. Phys., 13, 1141-1165, doi:10.5194/acp-13-1141-2013, 2013.

Andreae, M. O. and Merlet, P.: Emission of trace gases and aerosols from biomass burning, Global Biogeochem. Cy. 15, 955-966, 2001.

Baasandorj, M., Millet, D. B., Hu, L., Mitroo, D., and Williams, B. J.: Measuring acetic and formic acid by proton-transferreaction mass spectrometry: sensitivity, humidity dependence, and quantifying interferences, Atmos. Meas. Tech., 8, 13031321, doi:10.5194/amt-8-1303-2015, 2015.

Bandow, H., Washida, N., and Akimoto, H.: Ring-cleavage reactions of aromatic hydrocarbons studied by FT-IR spectroscopy. I. Photooxidation of toluene and benzene in the $\mathrm{NO}_{x}$-Air System, B. Chem. Soc. Jpn., 58, 2531-2540, 1985.

Barmet, P., Dommen, J., DeCarlo, P. F., Tritscher, T., Praplan, A. P., Platt, S. M., Prévôt, A. S. H., Donahue, N. M., and Baltensperger, $\mathrm{U} .: \mathrm{OH}$ clock determination by proton transfer reaction mass spectrometry at an environmental chamber, Atmos. Meas. Tech., 5, 647-656, doi:10.5194/amt-5-647-2012, 2012.

Bian, Q., May, A. A., Kreidenweis, S. M., and Pierce, J. R.: Investigation of particle and vapor wall-loss effects on controlled wood-smoke smog-chamber experiments, Atmos. Chem. Phys., 15, 11027-11045, doi:10.5194/acp-15-11027-2015, 2015.

Bølling, A. K., Pagels, J., Yttri, K. E., Barregard, L., Sallsten, G., Schwarze, P. E., and Boman, C.: Health effects of residential wood smoke particles: the importance of combustion conditions and physicochemical particle properties, Part. Fibre Toxicol., 6, doi:10.1186/1743-8977-6-29, 2009.

Bruns, E. A., Krapf, M., Orasche, J., Huang, Y., Zimmermann, R., Drinovec, L., Mocnik, G., El-Haddad, I., Slowik, J. G., Dommen, J., Baltensperger, U., and Prévôt, A. S. H.: Characterization of primary and secondary wood combustion products generated un- der different burner loads, Atmos. Chem. Phys., 15, 2825-2841, doi:10.5194/acp-15-2825-2015, 2015a.

Bruns, E. A., El Haddad, I., Keller, A., Klein, F., Kumar, N. K., Pieber, S. M., Corbin, J. C., Slowik, J. G., Brune, W. H., Baltensperger, U., and Prévôt, A. S. H.: Inter-comparison of laboratory smog chamber and flow reactor systems on organic aerosol yield and composition, Atmos. Meas. Tech., 8, 23152332, doi:10.5194/amt-8-2315-2015, 2015. 2015b.

Bruns, E. A., El Haddad, I., Slowik, J. G., Kilic, D., Klein, F., Baltensperger, U., and Prévôt, A. S. H.: Identification of significant precursor gases of secondary organic aerosols from residential wood combustion, Sci. Rep., 6, 27881, doi:10.1038/srep27881, 2016.

Buhr, K., van Ruth, S., and Delahunty, C.: Analysis of volatile flavour compounds by Proton Transfer Reaction-Mass Spectrometry: fragmentation patterns and discrimination between isobaric and isomeric compounds, Int. J. Mass. Spectrom., 221, 1-7, 2002.

Cappellin, L., Karl, T., Probst, M., Ismailova, O., Winkler, P. M., Soukoulis, C., Aprea, E., Märk, T. D., Gasperi, F., and Biasioli, F.: On quantitative determination of volatile organic compound concentrations using proton transfer reaction time-of-flight mass spectrometry, Environ. Sci. Technol., 46, 2283-2290, 2012.

Chan, A. W. H., Kautzman, K. E., Chhabra, P. S., Surratt, J. D., Chan, M. N., Crounse, J. D., Kürten, A., Wennberg, P. O., Flagan, R. C., and Seinfeld, J. H.: Secondary organic aerosol formation from photooxidation of naphthalene and alkylnaphthalenes: implications for oxidation of intermediate volatility organic compounds (IVOCs), Atmos. Chem. Phys., 9, 3049-3060, doi:10.5194/acp-9-3049-2009, 2009.

Chebbi, A. and Carlier, P.: Carboxylic acids in the troposphere, occurrence, sources, and sinks: A review, Atmos. Environ., 30, 4233-4249, 1996.

Christian, T. J., Kleiss, B., Yokelson, R. J., Holzinger, R., Crutzen, P. J., Hao, W. M., Saharjo, B. H., and Ward, D. E.: Comprehensive laboratory measurements of biomass-burning emissions: 1 . Emissions from Indonesian, African, and other fuels, J. Geophys. Res.-Atmos., 108, 4719, doi:10.1029/2003JD003704, 2003.

Christian, T. J., Kleiss, B., Yokelson, R. J., Holzinger, R., Crutzen, P. J., Hao, W. M., Shirai, T., and Blake, D. R.: Comprehensive laboratory measurements of biomass-burning emissions: 2. First intercomparison of open-path FTIR, PTR-MS, and GC-MS/FID/ECD, J. Geophys. Res.-Atmos., 109, D02311, doi:10.1029/2003JD003874, 2004.

Coggon, M. M., Veres, P. R., Yuan, B., Koss, A., Warneke, C., Gilman, J. B., Lerner, B. M., Peischl, J., Aikin, K. C., Stockwell, C. E., Hatch, L. E., Ryerson, T. B., Roberts, J. M., Yokelson, R. J., and de Gouw, J. A.: Emissions of nitrogen-containing organic compounds from the burning of herbaceous and arboraceous biomass: Fuel composition dependence and the variability of commonly used nitrile tracers, Geophys. Res. Lett., 43, 99039912, 2016.

Crippa, M., DeCarlo, P. F., Slowik, J. G., Mohr, C., Heringa, M. F., Chirico, R., Poulain, L., Freutel, F., Sciare, J., Cozic, J., Di Marco, C. F., Elsasser, M., Nicolas, J. B., Marchand, N., Abidi, E., Wiedensohler, A., Drewnick, F., Schneider, J., Borrmann, S., Nemitz, E., Zimmermann, R., Jaffrezo, J.-L., Prévôt, A. S. H., and Baltensperger, U.: Wintertime aerosol chemical composition and source apportionment of the organic fraction in the 
metropolitan area of Paris, Atmos. Chem. Phys., 13, 961-981, doi:10.5194/acp-13-961-2013, 2013.

de Gouw, J. A., Warneke, C., Parrish, D. D., Holloway, J. S., Trainer, M., and Fehsenfeld, F. C.: Emission sources and ocean uptake of acetonitrile $\left(\mathrm{CH}_{3} \mathrm{CN}\right)$ in the atmosphere, J. Geophys. Res.Atmos., 108, 4329, doi:10.1029/2002JD002897, 2003.

de Gouw, J. A., Warneke, C., Stohl, A., Wollny, A. G., Brock, C. A., Cooper, O. R., Holloway, J. S., Trainer, M., Fehsenfeld, F. C., Atlas, E. L., Donnelly, S. G., Stroud, V., and Lueb, A.: Volatile organic compounds composition of merged and aged forest fire plumes from Alaska and western Canada, J. Geophys. Res.-Atmos., 111, D10303, doi:10.1029/2005JD006175, 2006.

de Gouw, J. A., Welsh-Bon, D., Warneke, C., Kuster, W. C., Alexander, L., Baker, A. K., Beyersdorf, A. J., Blake, D. R., Canagaratna, M., Celada, A. T., Huey, L. G., Junkermann, W., Onasch, T. B., Salcido, A., Sjostedt, S. J., Sullivan, A. P., Tanner, D. J., Vargas, O., Weber, R. J., Worsnop, D. R., Yu, X. Y., and Zaveri, R.: Emission and chemistry of organic carbon in the gas and aerosol phase at a sub-urban site near Mexico City in March 2006 during the MILAGRO study, Atmos. Chem. Phys., 9, 34253442, doi:10.5194/acp-9-3425-2009, 2009.

Dunne, E., Galbally, I. E., Lawson, S., and Patti, A.: Interference in the PTR-MS measurement of acetonitrile at $m / z 42$ in polluted urban air - A study using switchable reagent ion PTR-MS, Int. J. Mass. Spectrom. 319-320, 40-47, 2012.

Evtyugina, M., Alves, C., Calvo, A., Nunes, T., Tarelho, L., Duarte, M., Prozil, S. O., Evtuguin, D. V., and Pio, C.: VOC emissions from residential combustion of Southern and mid-European woods, Atmos. Environ. 83, 90-98, 2014.

Fu, P. P., Xia, Q., Sun, X., and Yu, H.: Phototoxicity and environmental transformation of polycyclic aromatic hydrocarbons (PAHs) - light-induced reactive oxygen species, lipid peroxidation, and DNA damage, J. Environ. Sci. Heal. C, 30, 1-41, 2012.

Gaeggeler, K., Prevot, A. S. H., Dommen, J., Legreid, G., Reimann, S., and Baltensperger, U.: Residential wood burning in an Alpine valley as a source for oxygenated volatile organic compounds, hydrocarbons and organic acids, Atmos. Environ., 42, 82788287, 2008.

Gilman, J. B., Lerner, B. M., Kuster, W. C., Goldan, P. D., Warneke, C., Veres, P. R., Roberts, J. M., de Gouw, J. A., Burling, I. R., and Yokelson, R. J.: Biomass burning emissions and potential air quality impacts of volatile organic compounds and other trace gases from fuels common in the US, Atmos. Chem. Phys., 15, 13915-13938, doi:10.5194/acp-15-13915-2015, 2015.

Glasius, M., Ketzel, M., Wåhlin, P., Jensen, B., Mønster, J., Berkowicz, R., and Palmgren, F.: Impact of wood combustion on particle levels in a residential area in Denmark, Atmos. Environ., 40, 7115-7124, 2006.

Gómez Alvarez, E., Borrás, E., Viidanoja, J., and Hjorth, J.: Unsaturated dicarbonyl products from the $\mathrm{OH}$-initiated photo-oxidation of furan, 2-methylfuran and 3-methylfuran, Atmos. Environ., 43, 1603-1612, 2009.

Gonçalves, C., Alves, C., and Pio, C.: Inventory of fine particulate organic compound emissions from residential wood combustion in Portugal, Atmos. Environ., 50, 297-306, 2012.

Goode, J. G., Yokelson, R. J., Ward, D. E., Susott, R. A., Babbitt, R. E., Davies, M. A., and Hao, W. M.: Measurements of excess $\mathrm{O}_{3}, \mathrm{CO}_{2}, \mathrm{CO}, \mathrm{CH}_{4}, \mathrm{C}_{2} \mathrm{H}_{4}, \mathrm{C}_{2} \mathrm{H}_{2}, \mathrm{HCN}, \mathrm{NO}, \mathrm{NH}_{3}$, $\mathrm{HCOOH}, \mathrm{CH}_{3} \mathrm{COOH}, \mathrm{HCHO}$, and $\mathrm{CH}_{3} \mathrm{OH}$ in 1997 Alaskan biomass burning plumes by airborne Fourier transform infrared spectroscopy (AFTIR), J. Geophys. Res.-Atmos., 105, 2214722166, 2000.

Grieshop, A. P., Logue, J. M., Donahue, N. M., and Robinson, A. L.: Laboratory investigation of photochemical oxidation of organic aerosol from wood fires 1: measurement and simulation of organic aerosol evolution, Atmos. Chem. Phys., 9, 1263-1277, doi:10.5194/acp-9-1263-2009, 2009a.

Grieshop, A. P., Donahue, N. M., and Robinson, A. L.: Laboratory investigation of photochemical oxidation of organic aerosol from wood fires 2: analysis of aerosol mass spectrometer data, Atmos. Chem. Phys., 9, 2227-2240, doi:10.5194/acp-9-2227-2009, $2009 b$.

Guofeng, S., Siye, W., Wen, W., Yanyan, Z., Yujia, M., Bin, W., Rong, W., Wei, L., Huizhong, S., Ye, H., Yifeng, Y., Wei, W., Xilong, W., Xuejun, W. and Shu, T.: Emission factors, size distributions, and emission inventories of carbonaceous particulate matter from residential wood combustion in rural China, Environ. Sci. Technol., 46, 4207-4214, 2012.

Hansson, K.-M., Samuelsson, J., Tullin, C., and Åmand, L.-E.: Formation of $\mathrm{HNCO}, \mathrm{HCN}$, and $\mathrm{NH}_{3}$ from the pyrolysis of bark and nitrogen-containing model compounds, Combust. Flame, 137, 265-277, 2004.

Hedberg, E., Kristensson, A., Ohlsson, M., Johansson, C., Johansson, P.-A., Swietlicki, E., Vesely, V., Wideqvist, U., and Westerholm, R.: Chemical and physical characterization of emissions from birch wood combustion in a wood stove, Atmos. Environ., 36, 4823-4837, 2002.

Hennigan, C. J., Sullivan, A. P., Collett, J. L., and Robinson, A. L.: Levoglucosan stability in biomass burning particles exposed to hydroxyl radicals, Geophys. Res. Lett., 37, L09806, doi:10.1029/2010GL043088, 2010.

Herich, H., Gianini, M. F. D., Piot, C., Močnik, G., Jaffrezo, J. L., Besombes, J. L., Prévôt, A. S. H., and Hueglin, C.: Overview of the impact of wood burning emissions on carbonaceous aerosols and PM in large parts of the Alpine region, Atmos. Environ., 89, 64-75, 2014.

Heringa, M. F., DeCarlo, P. F., Chirico, R., Tritscher, T., Dommen, J., Weingartner, E., Richter, R., Wehrle, G., Prévôt, A. S. H., and Baltensperger, U.: Investigations of primary and secondary particulate matter of different wood combustion appliances with a high-resolution time-of-flight aerosol mass spectrometer, Atmos. Chem. Phys., 11, 5945-5957, doi:10.5194/acp-11-59452011, 2011.

Hobbs, P. V., Sinha, P., Yokelson, R. J., Christian, T. J., Blake, D. R., Gao, S., Kirchstetter, T. W., Novakov, T., and Pilewskie, P.: Evolution of gases and particles from a savanna fire in South Africa, J. Geophys. Res.-Atmos., 108, 8485, doi:10.1029/2002JD002352, 2003.

Holzinger, R., Warneke, C., Hansel, A., Jordan, A., Lindinger, W., Scharffe, D.H., Schade, G., and Crutzen, P. J.: Biomass burning as a source of formaldehyde, acetaldehyde, methanol, acetone, acetonitrile, and hydrogen cyanide, Geophys. Res. Lett., 26, 1161-1164, 1999.

Holzinger, R., Williams, J., Salisbury, G., Klüpfel, T., de Reus, M., Traub, M., Crutzen, P. J., and Lelieveld, J.: Oxygenated compounds in aged biomass burning plumes over the Eastern Mediterranean: evidence for strong secondary production 
of methanol and acetone, Atmos. Chem. Phys., 5, 39-46, doi:10.5194/acp-5-39-2005, 2005.

IPCC: Climate Change 2013: The Physical Science Basis, Contribution of Working Group I to the Fifth Assessment Report of the Intergovernmental Panel on Climate Change, edited by: Stocker, T. F., Qin, D., Plattner, G.-K., Tignor, M., Allen, S. K., Boschung, J., Nauels, A., Xia, Y., Bex, V., and Midgley, P. M., Cambridge University Press, Cambridge, UK and New York, USA, 2013.

Ito, A. and Penner, J. E.: Global estimates of biomass burning emissions based on satellite imagery for the year 2000, J. Geophys. Res.-Atmos., 109, D14S05, doi:10.1029/2003JD004423, 2004.

Jordan, A., Haidacher, S., Hanel, G., Hartungen, E., Märk, L., Seehauser, H., Schottkowsky, R., Sulzer, P., and Märk, T. D.: A high resolution and high sensitivity proton-transfer-reaction time-offlight mass spectrometer (PTR-TOF-MS), Int. J. Mass. Spectrom., 286, 122-128, 2009.

Jordan, T. B. and Seen, A. J.: Effect of airflow setting on the organic composition of woodheater emissions, Environ. Sci. Technol., 39, 3601-3610, 2005.

Jost, C., Trentmann, J., Sprung, D., Andreae, M. O., McQuaid, J. B., and Barjat, H.: Trace gas chemistry in a young biomass burning plume over Namibia: Observations and model simulations, J. Geophys. Res.-Atmos., 108, 8482, doi:10.1029/2002JD002431, 2003.

Kistler, M., Schmidl, C., Padouvas, E., Giebl, H., Lohninger, J., Ellinger, R., Bauer, H., and Puxbaum, H.: Odor, gaseous and $\mathrm{PM}_{10}$ emissions from small scale combustion of wood types indigenous to Central Europe, Atmos. Environ., 51, 86-93, 2012.

Krecl, P., Hedberg Larsson, E., Ström, J., and Johansson, C.: Contribution of residential wood combustion and other sources to hourly winter aerosol in Northern Sweden determined by positive matrix factorization, Atmos. Chem. Phys., 8, 3639-3653, doi:10.5194/acp-8-3639-2008, 2008.

Kroll, J. H. and Seinfeld, J. H.: Chemistry of secondary organic aerosol: formation and evolution of low-volatility organics in the atmosphere, Atmos. Environ., 42, 3593-3624, 2008.

Lindinger, W., Hansel, A., and Jordan, A.: On-line monitoring of volatile organic compounds at pptv levels by means of protontransfer-reaction mass spectrometry (PTR-MS) medical applications, food control and environmental research, Int. J. Mass. Spectrom., 173, 191-241, 1998.

Mason, S. A., Field, R. J., Yokelson, R. J., Kochivar, M. A., Tinsley, M. R., Ward, D. E., and Hao, W. M.: Complex effects arising in smoke plume simulations due to inclusion of direct emissions of oxygenated organic species from biomass combustion, J. Geophys. Res.-Atmos., 106, 12527-12539, 2001.

McDonald, J. D., Zielinska, B., Fujita, E. M., Sagebiel, J. C., Chow, J. C., and Watson, J. G.: Fine particle and gaseous emission rates from residential wood combustion, Environ. Sci. Technol., 34, 2080-2091, 2000.

Midey, A. J., Williams, S., Miller, T. M., and Viggiano, A. A.: Reactions of $\mathrm{O}_{2}^{+}, \mathrm{NO}^{+}$and $\mathrm{H}_{3} \mathrm{O}^{+}$with methylcyclohexane $\left(\mathrm{C}_{7} \mathrm{H}_{14}\right)$ and cyclooctane $\left(\mathrm{C}_{8} \mathrm{H}_{16}\right)$ from 298 to $700 \mathrm{~K}$, Int. J. Mass. Spectrom., 222, 413-430, 2003.

Müller, M., Anderson, B. E., Beyersdorf, A. J., Crawford, J. H., Diskin, G. S., Eichler, P., Fried, A., Keutsch, F. N., Mikoviny, T., Thornhill, K. L., Walega, J. G., Weinheimer, A. J., Yang, M., Yokelson, R. J., and Wisthaler, A.: In situ measurements and modeling of reactive trace gases in a small biomass burning plume, Atmos. Chem. Phys., 16, 3813-3824, doi:10.5194/acp16-3813-2016, 2016.

Nozière, B., Kalberer, M., Claeys, M., Allan, J., D’Anna, B., Decesari, S., Finessi, E., Glasius, M., Grgić, I., Hamilton, J. F., Hoffmann, T., Iinuma, Y., Jaoui, M., Kahnt, A., Kampf, C. J., Kourtchev, I., Maenhaut, W., Marsden, N., Saarikoski, S., Schnelle-Kreis, J., Surratt, J. D., Szidat, S., Szmigielski, R., and Wisthaler, A.: The molecular identification of organic compounds in the atmosphere: state of the art and challenges, Chem. Rev., 115, 3919-3983, 2015.

Overend, R. and Paraskevopoulos, G.: Rates of hydroxyl radical reactions, 4. Reactions with methanol, ethanol, 1-propanol, and 2propanol at 296 K, J. Phys. Chem., 82, 1329-1333, 1978.

Ozil, F., Tschamber, V., Haas, F., and Trouvé, G.: Efficiency of catalytic processes for the reduction of $\mathrm{CO}$ and $\mathrm{VOC}$ emissions from wood combustion in domestic fireplaces, Fuel Process. Technol., 90, 1053-1061, 2009.

Paraskevopoulou, D., Liakakou, E., Gerasopoulos, E., and Mihalopoulos, N.: Sources of atmospheric aerosol from long-term measurements (5 years) of chemical composition in Athens, Greece, Sci. Total Environ., 527-528, 165-178, 2015.

Paulot, F., Wunch, D., Crounse, J. D., Toon, G. C., Millet, D. B., DeCarlo, P. F., Vigouroux, C., Deutscher, N. M., González Abad, G., Notholt, J., Warneke, T., Hannigan, J. W., Warneke, C., de Gouw, J. A., Dunlea, E. J., De Mazière, M., Griffith, D. W. T., Bernath, P., Jimenez, J. L., and Wennberg, P. O.: Importance of secondary sources in the atmospheric budgets of formic and acetic acids, Atmos. Chem. Phys., 11, 1989-2013, doi:10.5194/acp-11-1989-2011, 2011.

Pettersson, E., Boman, C., Westerholm, R., Boström, D., and Nordin, A.: Stove performance and emission characteristics in residential wood $\log$ and pellet combustion, part 2: wood stove, Energ. Fuel, 25, 315-323, 2011.

Platt, S. M., El Haddad, I., Zardini, A. A., Clairotte, M., Astorga, C., Wolf, R., Slowik, J. G., Temime-Roussel, B., Marchand, N., Ježek, I., Drinovec, L., Mocnik, G., Möhler, O., Richter, R., Barmet, P., Bianchi, F., Baltensperger, U., and Prévôt, A. S. H.: Secondary organic aerosol formation from gasoline vehicle emissions in a new mobile environmental reaction chamber, Atmos. Chem. Phys., 13, 9141-9158, doi:10.5194/acp-13-91412013, 2013.

Pouli, A. E., Hatzinikolaou, D. G., Piperi, C., Stavridou, A., Psallidopoulos, M. C., and Stavrides, J. C.: The cytotoxic effect of volatile organic compounds of the gas phase of cigarette smoke on lung epithelial cells, Free Radical Bio. Med., 34, 345-355, 2003.

Praplan, A. P., Hegyi-Gaeggeler, K., Barmet, P., Pfaffenberger, L., Dommen, J., and Baltensperger, U.: Online measurements of water-soluble organic acids in the gas and aerosol phase from the photooxidation of 1,3,5-trimethylbenzene, Atmos. Chem. Phys., 14, 8665-8677, doi:10.5194/acp-14-8665-2014, 2014.

Reda, A. A., Czech, H., Schnelle-Kreis, J., Sippula, O., Orasche, J., Weggler, B., Abbaszade, G., Arteaga-Salas, J. M., Kortelainen, M., Tissari, J., Jokiniemi, J., Streibel, T., and Zimmermann, R.: Analysis of gas-phase carbonyl compounds in emissions from modern wood combustion appliances: influence of wood type and combustion appliance, Energ. Fuel, 29, 3897-3907, 2015.

Sato, K., Hatakeyama, S., and Imamura, T.: Secondary organic aerosol formation during the photooxidation of toluene: $\mathrm{NO}_{x}$ 
dependence of chemical composition, J. Phys. Chem. A, 111, 9796-9808, 2007.

Schauer, J. J., Kleeman, M. J., Cass, G. R., and Simoneit, B. R. T.: Measurement of emissions from air pollution sources, 3. $\mathrm{C}_{1}-\mathrm{C}_{29}$ organic compounds from fireplace combustion of wood, Environ. Sci. Technol., 35, 1716-1728, 2001.

Schmidl, C., Luisser, M., Padouvas, E., Lasselsberger, L., Rzaca, M., Ramirez-Santa Cruz, C., Handler, M., Peng, G., Bauer, H., and Puxbaum, H.: Particulate and gaseous emissions from manually and automatically fired small scale combustion systems, Atmos. Environ., 45, 7443-7454, 2011.

Shao, M., Lu, S., Liu, Y., Xie, X., Chang, C., Huang, S., and Chen, Z.: Volatile organic compounds measured in summer in Beijing and their role in ground-level ozone formation, J. Geophys. Res.Atmos., 114, D00G06, doi:10.1029/2008JD010863, 2009.

Singh, H. B., Salas, L., Herlth, D., Kolyer, R., Czech, E., Viezee, W., Li, Q., Jacob, D. J., Blake, D., Sachse, G., Harward, C.N., Fuelberg, H., Kiley, C. M., Zhao, Y., and Kondo, Y.: In situ measurements of $\mathrm{HCN}$ and $\mathrm{CH}_{3} \mathrm{CN}$ over the Pacific Ocean: Sources, sinks, and budgets, J. Geophys. Res.-Atmos., 108, 8795, doi:10.1029/2002JD003006, 2003.

Singh, H. B., Salas, L. J., Chatfield, R. B., Czech, E., Fried, A., Walega, J., Evans, M. J., Field, B. D., Jacob, D. J., Blake, D., Heikes, B., Talbot, R., Sachse, G., Crawford, J. H., Avery, M. A., Sandholm, S., and Fuelberg, H.: Analysis of the atmospheric distribution, sources, and sinks of oxygenated volatile organic chemicals based on measurements over the Pacific during TRACE-P, J. Geophys. Res.-Atmos., 109, D15S07, doi:10.1029/2003JD003883, 2004.

Stockwell, C. E., Veres, P. R., Williams, J., and Yokelson, R. J.: Characterization of biomass burning emissions from cooking fires, peat, crop residue, and other fuels with high-resolution proton-transfer-reaction time-of-flight mass spectrometry, Atmos. Chem. Phys., 15, 845-865, doi:10.5194/acp-15-845-2015, 2015.

Šyc, M., Horák, J., Hopan, F., Krpec, K., Tomšej, T., Ocelka, T., and Pekárek, V.: Effect of fuels and domestic heating appliance types on emission factors of selected organic pollutants, Environ. Sci. Technol., 45, 9427-9434, 2011.

Tabazadeh, A., Yokelson, R. J., Singh, H. B., Hobbs, P. V., Crawford, J. H., and Iraci, L. T.: Heterogeneous chemistry involving methanol in tropospheric clouds, Geophys. Res. Lett., 31, L06114, doi:10.1029/2003GL018775, 2004.

Tao, J., Gao, J., Zhang, L., Zhang, R., Che, H., Zhang, Z., Lin, Z., Jing, J., Cao, J., and Hsu, S.-C.: $\mathrm{PM}_{2.5}$ pollution in a megacity of southwest China: source apportionment and implication, Atmos. Chem. Phys., 14, 8679-8699, doi:10.5194/acp-14-86792014, 2014.
Warneke, C., de Gouw, J. A., Kuster, W. C., Goldan, P. D., and Fall, R.: Validation of atmospheric VOC measurements by proton-transfer-reaction mass spectrometry using a gaschromatographic preseparation method, Environ. Sci. Technol., 37, 2494-2501, 2003.

Warneke, C., de Gouw, J. A., Stohl, A., Cooper, O. R., Goldan, P. D., Kuster, W. C., Holloway, J. S., Williams, E. J., Lerner, B. M., McKeen, S. A., Trainer, M., Fehsenfeld, F. C., Atlas, E. L., Donnelly, S. G., Stroud, V., Lueb, A., and Kato, S.: Biomass burning and anthropogenic sources of $\mathrm{CO}$ over New England in the summer 2004, J. Geophys. Res.-Atmos., 111, D23S15, doi:10.1029/2005JD006878, 2006.

Warneke, C., Roberts, J. M., Veres, P., Gilman, J., Kuster, W. C., Burling, I., Yokelson, R., and de Gouw, J. A.: VOC identification and inter-comparison from laboratory biomass burning using PTR-MS and PIT-MS, Int. J. Mass. Spectrom., 303, 6-14, 2011.

Yokelson, R. J., Bertschi, I. T., Christian, T. J., Hobbs, P. V., Ward, D. E., and Hao, W. M.: Trace gas measurements in nascent, aged, and cloud-processed smoke from African savanna fires by airborne Fourier transform infrared spectroscopy (AFTIR), J. Geophys. Res.-Atmos., 108, 8478, doi:10.1029/2002JD002322, 2003.

Yokelson, R. J., Christian, T. J., Karl, T. G., and Guenther, A.: The tropical forest and fire emissions experiment: laboratory fire measurements and synthesis of campaign data, Atmos. Chem. Phys., 8, 3509-3527, doi:10.5194/acp-8-3509-2008, 2008.

Yokelson, R. J., Crounse, J. D., DeCarlo, P. F., Karl, T., Urbanski, S., Atlas, E., Campos, T., Shinozuka, Y., Kapustin, V., Clarke, A. D., Weinheimer, A., Knapp, D. J., Montzka, D. D., Holloway, J., Weibring, P., Flocke, F., Zheng, W., Toohey, D., Wennberg, P. O., Wiedinmyer, C., Mauldin, L., Fried, A., Richter, D., Walega, J., Jimenez, J. L., Adachi, K., Buseck, P. R., Hall, S. R., and Shetter, R.: Emissions from biomass burning in the Yucatan, Atmos. Chem. Phys., 9, 5785-5812, doi:10.5194/acp-9-5785-2009, 2009.

Zhang, X., Cappa, C. D., Jathar, S. H., McVay, R. C., Ensberg, J. J., Kleeman, M. J., and Seinfeld, J. H.: Influence of vapor wall loss in laboratory chambers on yields of secondary organic aerosol, $\mathrm{P}$. Natl. Acad. Sci. USA, 111, 5802-5807, 2014. 